Biogeosciences Discuss., 8, 6415-6445, 2011

www.biogeosciences-discuss.net/8/6415/2011/

doi:10.5194/bgd-8-6415-2011

(C) Author(s) 2011. CC Attribution 3.0 License.

\title{
Soil warming in a cool-temperate mixed forest with peat soil enhanced heterotrophic and basal respiration rates but $Q_{10}$ remained unchanged
}

Warming effect on soil heterotrophic respiration

M. Aguilos et al.

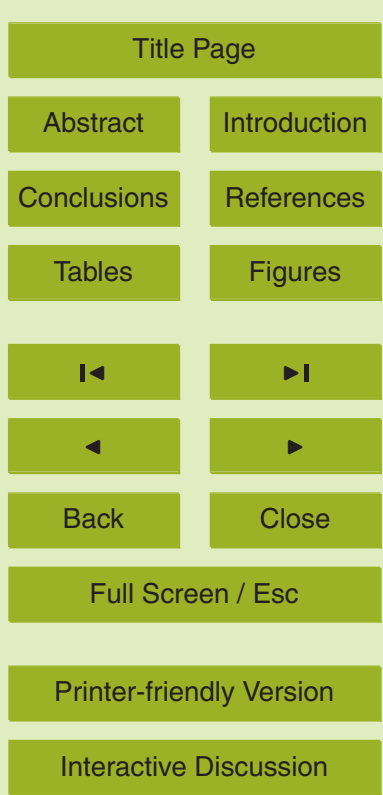

M. Aguilos ${ }^{1}$, K. Takagi ${ }^{2}$, N. Liang ${ }^{3}$, Y. Watanabe ${ }^{2}$, S. Goto ${ }^{3}$, Y. Takahashi ${ }^{3}$, H. Mukai ${ }^{3}$, and K. Sasa ${ }^{2}$

${ }^{1}$ Graduate School of Environmental Science, Hokkaido University, Sapporo, 060-0809 Japan

${ }^{2}$ Field Science Center for Northern Biosphere, Hokkaido University, Sapporo, 060-0809 Japan

${ }^{3}$ Center for Global Environmental Research, National Institute for Environmental Studies,

Tsukuba, 305-0056 Japan

Received: 7 June 2011 - Accepted: 29 June 2011 - Published: 7 July 2011

Correspondence to: M. Aguilos (maricar@fsc.hokudai.ac.jp)

Published by Copernicus Publications on behalf of the European Geosciences Union. 


\section{Abstract}

We conducted soil warming experiment in a cool-temperate forest with peat soil in northern Japan, during the snowless seasons of 2007-2009. Our objective was to determine whether or not the heterotrophic respiration rate and the temperature sensitivity would change by soil warming. We elevated the soil temperature by $3^{\circ} \mathrm{C}$ at 5 $\mathrm{cm}$ depth by means of overhead infrared heaters and continuously measured soil $\mathrm{CO}_{2}$ fluxes by using a fifteen-channel automated chamber system. Trenching treatment was also carried out to separate heterotrophic respiration and root respiration from the total soil respiration. The fifteen chambers were divided into three groups each with foplications for the control, unwarmed-trenched, and warm We found that heterotrophic respiration contributed $71 \%$ of the total soil respiration with the remaining $29 \%$ accounted to autotrophic respiration. Soil warming enhanced heterotrophic respiration by $74 \%$ (mean $6.11 \pm 3.07$ S.D. $\mu \mathrm{mol} \mathrm{m} \mathrm{m}^{-2} \mathrm{~s}^{-1}$ ) as compared to the unwarmed-trenched treatment (mean $3.52 \pm 1.74 \mu \mathrm{mol} \mathrm{m}^{-2} \mathrm{~s}^{-1}$ ). Soil $\mathrm{CO}_{2}$ efflux, 15 however, was weakly correlated with soil moisture, probably because the volumetric soil moisture (33-46\%) was within a plateau region for root and microbial activities. The enhancement in heterotrophic respiration with soil warming in our study suggests that global warming will accelerate the loss of carbon from forested peatlands more seriously than other upland forest soils. On the other hand, soil warming did not cause significant change in the temperature sensitivity, $Q_{10},(2.79$ and 2.74 determined using hourly efflux data for unwarmed- and warmed-trenched, respectively), but increased their basal respiration rate at $0^{\circ} \mathrm{C}\left(0.93\right.$ and $1.21 \mu \mathrm{mol} \mathrm{m} \mathrm{m}^{-2} \mathrm{~s}^{-1}$, respectively). Results suggest that if we predict the soil heterotrophic respiration rate in future warmer environment using the current relationship between soil temperature and heterotrophic
BGD

$8,6415-6445,2011$

\section{Warming effect on soil heterotrophic respiration}

M. Aguilos et al.

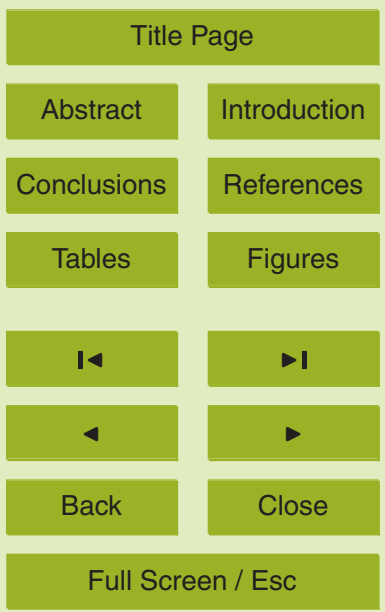

Printer-friendly Version

Interactive Discussion 


\section{Introduction}

Temperature sensitivity of soil carbon decomposition and the feedback to climate change has recently received considerable interest, because more than twice as much carbon is stored in soils as in the atmosphere (IPCC, 2007) and $\mathrm{CO}_{2}$ efflux from the 5 soils is the second largest flux in the global carbon cycle after gross primary production, with estimated annual emissions of $98 \mathrm{PgC} \mathrm{yr}^{-1}$ in 2008 , which exceeds anthropogenic $\mathrm{CO}_{2}$ release by an order of magnitude (Bond-Lamberty and Thomson, 2010). Accordingly, relatively small increase in soil respiration would provide strong positive feedback to the atmosphere by increasing the amount of atmospheric $\mathrm{CO}_{2}$ (Jenkinson

10 et al., 1991; Kirschbaum, 1995; Cox et al., 2000; Knorr et al., 2005). Forests contain about $45 \%$ of the global carbon stock and a large part of which is in the forest soils. Therefore, many soil warming experiments have been conducted in forests to reveal the warming effect on the soil respiration rate and the temperature sensitivity. Several studies reveal that the warming effect decreases after several years of the experiment caused by depletion of substrate availability or acclimation of decomposer community (Rustad et al., 2001; Melillo et al., 2002; Davidson and Janssens, 2006), and the feedback strength is not as large as the prediction obtained by assuming constant temperature sensitivity of decomposition of carbon stocks (Friedlingstein et al., 2006). However, many of these studies are conducted at upland mineral soils, where conditions are generally favorable for decomposition, resulting in relatively low carbon densities (Davidson and Janssens, 2006). On the other hand, Bellamy et al. (2005) have shown that recent losses of soil carbon in England and Wales are likely to have been offsetting absorption of carbon by terrestrial sinks, and peat soils and bogs lost carbon at a faster rate than upland soils. In addition, recent experimental evidence has confirmed that heterotrophic respiration increased in response to warming for at least eight years in a subarctic peatland (Dorrepaal et al., 2009). Thus long-term effect of climate warming on soil carbon is still under debate and more case studies especially for ecosystems with plentiful carbon stock in the soil are required before overlooking the effect (Davidson and Janssens, 2006).
BGD

$8,6415-6445,2011$

\section{Warming effect on soil heterotrophic respiration}

M. Aguilos et al.

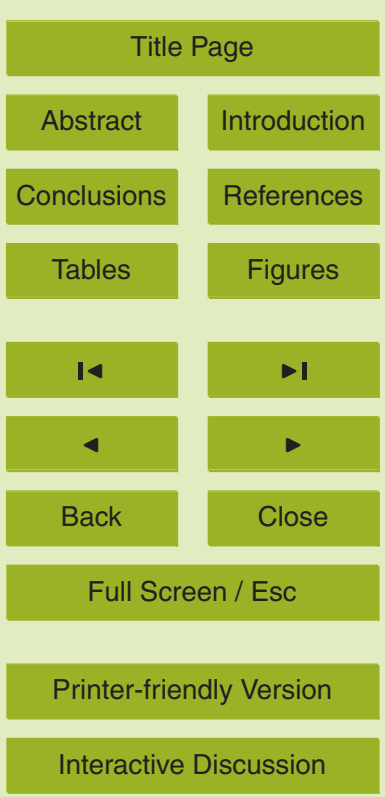


Hence, we conducted soil warming experiment in a cool-temperate mixed forest standing on peat soils, which contain abundant substrates. For precise evaluation of the warming effect on the respiration rate and temperature sensitivity, we adopted multi-channel automated chamber system which enables hourly measurement of soil 5 respiration rate throughout snow-free periods and covers spatial variability with large size and number of chambers $\left(4.05 \mathrm{~m}^{2}\right.$ in total for each treatment), overhead infrared heaters were added to increase soil temperature by $3^{\circ} \mathrm{C}$. Our results include (1) an observation on the response of soil heterotrophic respiration to elevated temperature and determination of its contribution to the total soil $\mathrm{CO}_{2}$ efflux during 2007-2009 snow10 free seasons; (2) an evaluation of their temperature sensitivities using the empiricallyderived $Q_{10}$ values; and (3) a regression analysis to explore how increased temperature affects soil water function as a predictor of soil respiration. While several studies have questioned the validity of using $Q_{10}$ 's (Lloyd and Taylor, 1994; Kirschbaum, 1995; Davidson et al., 2006; Bronson et al., 2008), we used the parameter because it offers a convenient point of comparison to previous studies. A major uncertainty in the future carbon cycle prediction is the assumption that the observed temperature sensitivity of soil respiration under the present climatic condition would hold in a future warmed climate. If there is a change in $Q_{10}$ under warming condition, the model simulations which assume constant $Q_{10}$ would over- or underestimate the soil respiration rate in the future.

\section{Materials and methods}

\subsection{Site description}

The experiment was conducted in a flat, low-lying elevation of Teshio Experimental Forest (TEEF), Hokkaido University, Northern Japan $\left(44^{\circ} 55^{\prime} \mathrm{N}\right.$ and $\left.142^{\circ} 01^{\prime} \mathrm{E}\right)$. The altitude of the site is about $20 \mathrm{~m}$ a.s.l. and the terrain is essentially flat with a gentle slope within $1^{\circ}$. It is a mid-latitude, cool-temperate ecosystem with an annual mean

\section{BGD}

$8,6415-6445,2011$

\section{Warming effect on soil heterotrophic respiration}

M. Aguilos et al.

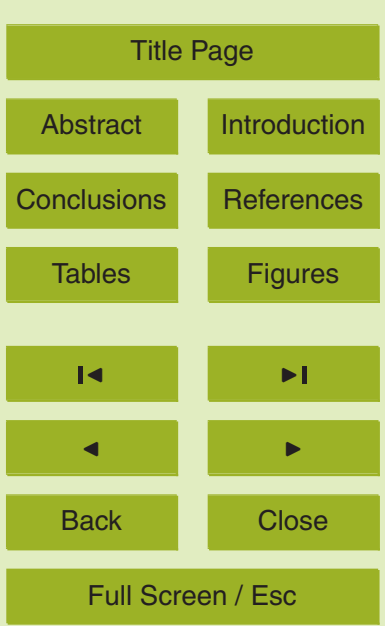

Printer-friendly Version

Interactive Discussion 
air temperature of $5.7^{\circ} \mathrm{C}$ (maximum $\sim 30^{\circ} \mathrm{C}$; minimum $\sim-30^{\circ} \mathrm{C}$ ). Annual precipitation is ca. $1000 \mathrm{~mm}$ and snow covers from late November to early April. The presence of very thick surface organic matter $(\sim 40 \mathrm{~cm})$ in the soil indicates a once peat land site that gone dry ca. $30 \mathrm{yr}$ ago, and surface litter layer is shallow.

5 In late 1970's, an artificial forest was established in the site. To mimic its original vegetation, the site was planted with Abies sachalinensis, Picea jezoensis, Quercus crispula, Betula ermanii, Betula platyphylla var. Japonica and Acer mono. At present, the tree density is 831 stems ha ${ }^{-1}$ and basal area is $20.7 \mathrm{~m}^{2} \mathrm{ha}^{-1}$. The understory had been dominated by dwarf bamboos (Sasa senanensis and Sasa kurilensis) for more 10 than 20 yr until October of 2006.

Prior to the conduct of the study, dense Sasa bamboos inside the $1480 \mathrm{~m}^{2}$ fenced experimental site were clear-cut in October, 2006. Cleared forest floor was maintained until the chamber installation in July, 2007 to diminish the influence of residual decomposing roots.

In October 2009 (the 3rd year of the experiment), soil sample cores of $100 \mathrm{~cm}^{3}$ each were collected near each of 15 chambers for $\mathrm{CO}_{2}$ efflux measurement, representing the soil organic carbon content of the whole study area. Dry bulk density was obtained by weighing the samples after 4 days of oven-drying at $80^{\circ} \mathrm{C}$. Carbon content was analyzed using an automatic NC analyzer (Sumigraph NC-900, Sumika Chemical Analysis

20 Service, Japan), attached to a gas chromatograph (GC-8A, Shimadzu, Corp., Japan). Three samples were analyzed for each core and the average indicated the carbon content of that soil core. The average carbon content and carbon density at $5 \mathrm{~cm}$ surface layer of the study site were $115 \pm 37.41 \mathrm{SD} \mathrm{gC} \mathrm{kg}^{-1}$ and $2.86 \pm 0.69 \mathrm{SD} \mathrm{kgC} \mathrm{m}^{-2}$, respectively, and there was no significant difference in the carbon content among treat-

\subsection{Experimental layout and soil warming}

Using the complete randomized design, the field manipulations consisting of 15 chambers were grouped into five. There were three chambers within each group
BGD

8, 6415-6445, 2011

\section{Warming effect on soil heterotrophic respiration}

M. Aguilos et al.

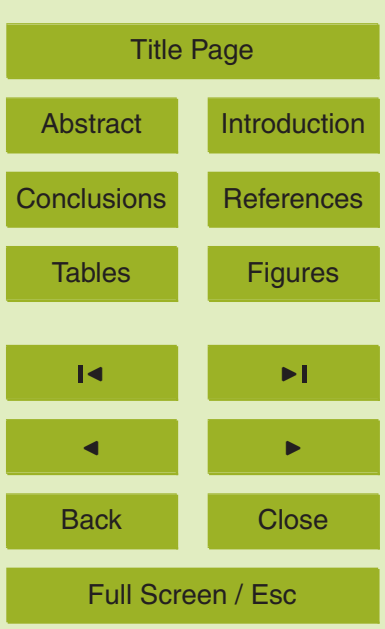

Printer-friendly Version

Interactive Discussion 
that were randomly assigned to one of the three treatments: (1) warmed-trenched; (2) unwarmed-trenched; and (3) served as undisturbed-control chamber (neither trenching nor warming). The use of five chambers for each treatment is within the recommended number of sampling points required to achieve $\pm 20 \%$ degree of precision 5 at $95 \%$ confidence interval (Liang et al., 2004). Warming effect on the heterotrophic respiration can be evaluated by the comparison between treatments (1) and (2), and proportion of heterotrophic respiration rate to soil respiration rate can be elucidated by the comparison between treatments (2) and (3).

We started soil warming on 20 August 2007, 40 days after setting up the chamber 10 systems and trenching. This continued until the snow covered the site. For the following years, warming period were from 22 March to 20 November for 2008, and from 22 April to 20 November for 2009.

The heating treatment was applied to one of the three chambers in each block making the soil temperature at $5 \mathrm{~cm}$ depth $3^{\circ} \mathrm{C}$ higher than other chambers. They were pipes anchored from the two sides of the chamber was installed to hold the $58 \mathrm{~cm}$ long, $800 \mathrm{~W}$ infrared heating lamps suspended at $1.6 \mathrm{~m}$ above the ground. A motionsensitive device that automatically turns-off the heater in case of troubles, e.g. strong wind, was also installed. Once fell on the ground, heating automatically stops preventing worst cases as forest fire.

We dug a trench $\sim 10 \mathrm{~cm}$ away from the sidewalls of the warmed and unwarmed chambers using the hand-held chainsaw. The depth was $\sim 30 \mathrm{~cm}$ below the ground surface. We inserted a $4 \mathrm{~mm}$ width PVC boards on the trench and backfilled remaining spaces with fine river sand to prevent growth of roots into the trenched plots. Newly emerged seedlings in the chambers were removed every few weeks, making no form of vegetation growing inside the chambers.

BGD

$8,6415-6445,2011$

\section{Warming effect on soil heterotrophic respiration}

M. Aguilos et al.

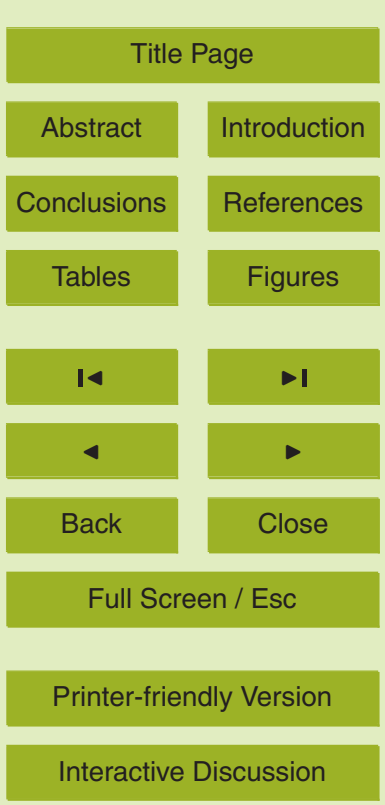




\subsection{Soil $\mathrm{CO}_{2}$ efflux and environment measurements}

The flow-through, non-steady-state automated chamber system was set-up. The system was originally designed by Liang et al. (2003 and 2004), however was improved to measure the rate of change in $\mathrm{CO}_{2}$ and water vapor over time in a closed chamber 5 (Takagi et al., 2009; Liang et al., 2010). The system was composed of 15 automated chambers and a control unit. The control unit included 15-channel gas sampler, an IRGA (LI-840, Li-Cor, Lincoln, NE, USA), and a data-logger (CR 1000, Campbell Scientific, Logan, UT, USA). Each of the 15 chambers had a dimension of $0.9 \times 0.9 \times 0.5 \mathrm{~m}$ high. The chambers were made of clear PVC board ( $2 \mathrm{~mm}$ thickness) attached to a $103 \times 3 \mathrm{~cm}$ plastic-coated steel pipe square frame. The chambers have PVC lids $(4 \mathrm{~mm}$ thickness) hinged at the sidewalls. These two lids were automatically opened during non-measurement and closed during measurement by two pneumatic cylinders (SCM20B, CKD Corp., Nagoya, Japan). The opening of lids during non-measurement allows precipitation and leaf litter reaching the enclosed soil surface so as to maintain the 15 natural condition within it. During measurements, air in the chamber was mixed by two micro fans (MF12B, Nihon Blower Ltd., Tokyo, Japan), air inside the chamber was circulated through the IRGA by a micro-diaphragm pump ( $5 \mathrm{~L} \mathrm{~min}^{-1}$; CM-50, Enomoto Ltd., Tokyo, Japan), and the rate of changes in $\mathrm{CO}_{2}$ and water vapor mole fraction were measured by the IRGA. Over $1 \mathrm{~h}$, the chambers were closed sequentially under the control of the data-logger. The data-logger acquired data output from the IRGA at $20 \mathrm{~s}$ intervals within $240 \mathrm{~s}$ for each chamber. Consecutively, the $\mathrm{CO}_{2}$ efflux rate was evaluated every hour for the 15 chambers during the snow-free periods.

Soil temperature at $5 \mathrm{~cm}$ depth and volumetric soil water content (SWC) from 3 to $8 \mathrm{~cm}$ depth were measured by type-T thermocouples (at $20 \mathrm{~s}$ intervals) and soil moisture sensors $\left(\mathrm{ECH}_{2} \mathrm{O} \mathrm{EC}-5\right.$, Decagon Devices Inc., Pullman, WA, USA) (at 1 min intervals) inside each chamber. Soil water measurement commenced nearly a month after the start of warming. The 30-min averages of soil and air temperatures, and volumetric soil water content for the 15 chambers were all recorded by the logger.
BGD

$8,6415-6445,2011$

\section{Warming effect on soil heterotrophic respiration}

M. Aguilos et al.

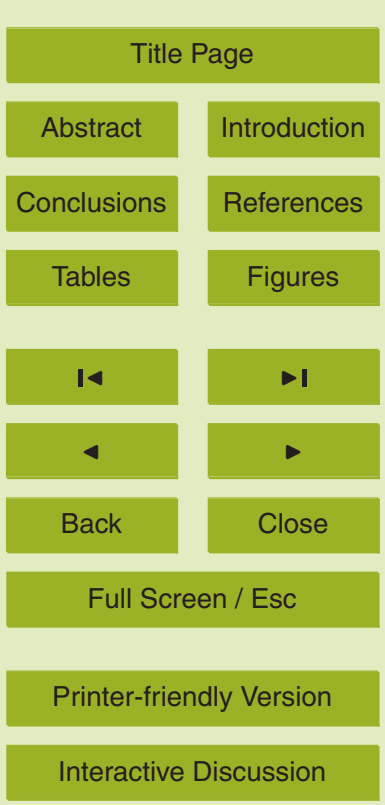


Soil $\mathrm{CO}_{2}$ efflux $\left(F_{\mathrm{c}}\right)$ was calculated using the equation:

$F_{\mathrm{c}}=\frac{k P V}{S(T+273.15)}\left(\frac{\Delta C}{\Delta t}+\frac{C}{(1000-W)} \frac{\Delta W}{\Delta t}\right)$

BGD

where $k$ is a constant $(120.28=1000 / 8.314) ; V$ and $S$ are the volume $\left(\mathrm{m}^{3}\right)$ and area $\left(\mathrm{m}^{2}\right)$ enclosed by the chamber, respectively; $P$ is the atmospheric pressure (constant 5 at $101.325 \mathrm{kPa}) ; T$ is the average air temperature $\left({ }^{\circ} \mathrm{C}\right)$ in the specific chamber that measured at about $25 \mathrm{~cm}$ height in the center of the chamber; $C$ and $W$ are the average $\mathrm{CO}_{2}\left(\mu \mathrm{mol} \mathrm{mol}^{-1}\right)$ and water vapor $\left(\mathrm{mmol} \mathrm{mol}^{-1}\right)$ mole fraction, respectively; and $\Delta C / \Delta t$ and $\Delta W / \Delta t$ are the rate of changes in $\mathrm{CO}_{2}$ and the water vapor mole fraction over time (s), respectively.

\subsection{Data processing and analysis}

The chamber system automatically records the change in $\mathrm{CO}_{2}$ and the water vapor mole fraction making it possible for an hourly efflux rate of the 15 chambers to be evaluated. However, the system sometimes failed to get the change correctly, e.g. lid-closing is disturbed by lack of air pressure of the pneumatic cylinders, or by falling branches. In order to detect the quality of the data, we checked the stationarity of the rate of change in $\mathrm{CO}_{2}(\Delta \mathrm{C} / \Delta t)$. The data-logger records 12 data for the calculation of the $\Delta C / \Delta t$ (i.e. $20 \mathrm{~s}$ interval for $240 \mathrm{~s}$ ) every $1 \mathrm{~h}$ for each chamber. We calculated the average $\Delta C / \Delta t$ for three cases: (a) using 10 data except first 2 data just after the change in measured chamber, (b) using 8 data removing both ends of the case (a) data, (c) using 6 data removing both ends of the case (b) data. The $\Delta C / \Delta t$ obtained by these three types of calculations would be the same if they were measured ideally. We evaluated the quality of $\Delta C / \Delta t$ by comparing $\Delta C / \Delta t \mathrm{~s}$ calculated by the three cases using the following two discriminants;

$$
\begin{aligned}
& \left|\Delta C_{\mathrm{a}} / \Delta t_{\mathrm{a}}-\Delta C_{\mathrm{b}} / \Delta t_{\mathrm{b}}\right| /\left|\Delta C_{\mathrm{a}} / \Delta t_{\mathrm{a}}\right|<\beta \\
{ }_{25} \quad & \left|\Delta C_{\mathrm{a}} / \Delta t_{\mathrm{a}}-\Delta C_{\mathrm{c}} / \Delta t_{\mathrm{c}}\right| /\left|\Delta C_{\mathrm{a}} / \Delta t_{\mathrm{a}}\right|<\beta
\end{aligned}
$$

\section{Warming effect on soil heterotrophic respiration}

M. Aguilos et al.

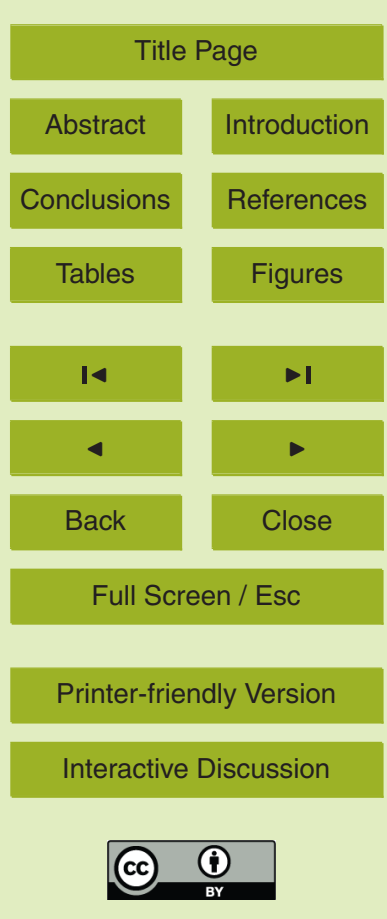


where the subscripts, $a, b, c$ correspond to the three cases, and $\beta$ is the threshold value. We chose 0.3 for $\beta$ after repeated trial and error, and the $\Delta C_{\mathrm{a}} / \Delta t_{\mathrm{a}}$ that passed both criteria (Eqs. 2 and 3 ) was used to evaluate the efflux. This quality checking successfully removed bad quality data (Fig. 1).

5 To discuss the temperature and soil moisture effect on the heterotrophic respiration or the contribution of heterotrophic respiration rate to the total soil respiration rate, the temperature, soil moisture and efflux data obtained from five chambers were averaged every hour for each treatment. The number of data to be averaged sometimes changed for each time and treatment because some of the five data were removed depending 10 on the result of quality control. However, lack of averaged data was a very rare case. Out of 38340 data obtained each for soil respiration, soil temperature, and soil water content only $308,154,156$, respectively were missing. These covered the 20 -month measurement period except for soil water content which covered only 19 months as it started late.

15 To examine temperature sensitivity of soil $\mathrm{CO}_{2}$ efflux $\left(F_{\mathrm{c}}\right)$, we conducted regression analysis using the soil temperature $\left(T_{\mathrm{s}}\right)$ as the environmental variable:

$F_{\mathrm{c}}=\operatorname{aexp}^{b T_{\mathrm{s}}}$

where coefficients $a$ and $b$ are the basal respiration rate (i.e., $F_{c}$ at temperature zero) and the sensitivity of $F_{\mathrm{c}}$ to $T_{\mathrm{s}}$, respectively. The $b$ values were also used to calculate 20 the $Q_{10}$ quotient (relative increase in $F_{\mathrm{c}}$ for a $10^{\circ} \mathrm{C}$ change in $T_{\mathrm{s}}$ ) as $Q_{10}=\exp ^{10 \mathrm{~b}}$.

We also determined the effect of soil moisture on soil $\mathrm{CO}_{2}$ efflux. In order to eliminate the effect of temperature on each measured soil $\mathrm{CO}_{2}$ efflux, we used temperaturenormalized soil $\mathrm{CO}_{2}$ efflux, which was calculated as the difference between measured soil $\mathrm{CO}_{2}$ efflux $\left(F_{\mathrm{cm}}\right)$ and the estimated efflux at the observed temperature using the regression curve obtained from each treatment $\left(F_{\mathrm{ce}}(t)\right)$ as, $F_{\mathrm{cm}}-F_{\mathrm{ce}}(t)$.

Repeated measures ANOVA was used to examine treatment effects on $\mathrm{CO}_{2}$ efflux. Data considered as outliers were not included in the analysis. Statistical analyses were carried out using SPSS (SPSS Science, Birmingham, UK).

\section{BGD}

8, 6415-6445, 2011

\section{Warming effect on soil heterotrophic respiration}

M. Aguilos et al.

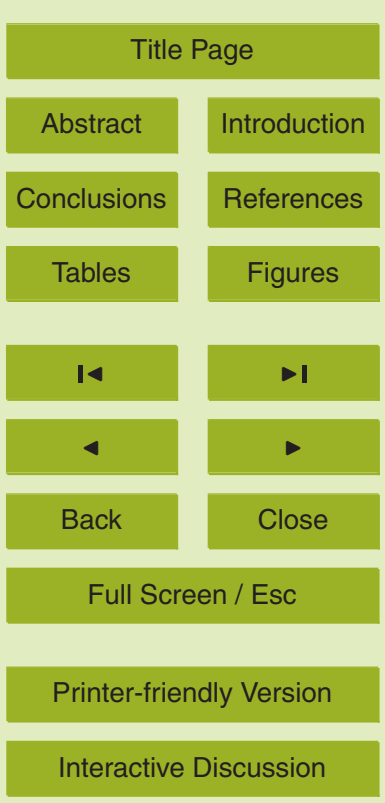

Interactive Discussion 


\section{Results}

\subsection{Soil temperature and moisture}

Soil warming increased soil temperature constantly across the 20-month measurement period (Fig. 2). Annual result revealed a warmer soil in warmed-trenched chambers 5 towards the last year of measurement period (2009) with an average soil temperature of $15.3^{\circ} \mathrm{C}$. This is $1^{\circ} \mathrm{C}$ higher compared to the average soil temperature in $2008\left(14.3^{\circ} \mathrm{C}\right.$, $p<0.001$ ).

During the snowless seasons of 2007-2009, the average soil temperature in warmed chambers was $14.5^{\circ} \mathrm{C}$ (ranges from 0.2 to $24.5^{\circ} \mathrm{C}$ ), this is $3.0 \pm 0.92 \mathrm{SD}^{\circ} \mathrm{C}$ higher than the unwarmed-trenched chambers with $11.5^{\circ} \mathrm{C}$ (ranges from -0.1 to $21.8^{\circ} \mathrm{C}$ ), and $3.1 \pm 0.87 \mathrm{SD}^{\circ} \mathrm{C}$ higher than the control (neither warming nor trenching) chambers with $11.4^{\circ} \mathrm{C}(p<0.001)$.

Soil water content (SWC) inside the warmed-trenched chambers (mean $39 \pm 1.6 \%$ S.D., ranging from 33 to $42 \%$ ) was drier by 4 and $3 \%$ compared with those in the unwarmed-trenched chambers ( $43 \pm 0.5 \%$ S.D., ranging from 41 to $44 \%$ ) and control chambers $(42 \pm 1.2 \%$ S.D., ranging from 38 to $46 \%)$, respectively $(p<0.001)$. Although SWC differences among treatments were significant, the differences were very small and the average SWC in warmed chambers (39\%) was still high.

\subsection{Soil $\mathrm{CO}_{2}$ efflux and the warming effect}

20 Soil $\mathrm{CO}_{2}$ effluxes in all the treatments roughly paralleled to the seasonal variation of soil temperature. Increasing the rate at the start of growing season in spring until summer and decreases towards leaf fall in autumn (Fig. 3). Soil warming increased the heterotrophic respiration rate consistently across the entire measurement period $(p<0.001)$. The efflux rate of control chamber was almost the same with that of warmed-trenched chamber in 2007, but was intermediate between the effluxes of warmed and unwarmed trenched chambers. Annual result revealed a gradually
BGD

$8,6415-6445,2011$

\section{Warming effect on soil heterotrophic respiration}

M. Aguilos et al.

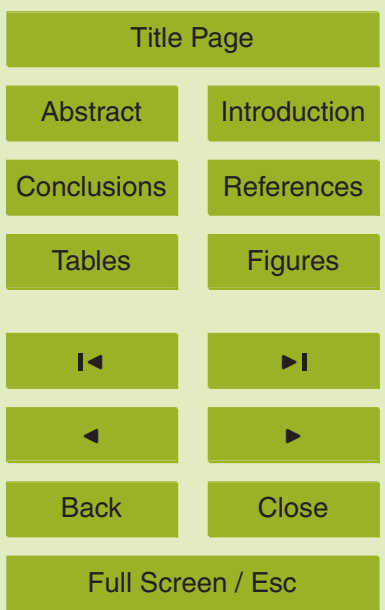

Printer-friendly Version

Interactive Discussion 
increasing heterotrophic respiration rate in elevated temperature with 4.67, 5.87, and $6.91\left(\mu \mathrm{mol} \mathrm{m}{ }^{-2} \mathrm{~s}^{-1}\right)$ in average during snow-free periods in 2007, 2008 and 2009, respectively.

Across all seasons within the 3-yr warming period, soil $\mathrm{CO}_{2}$ efflux was greatest in the 5 warmed-trenched chambers (Table 1 and Fig. 3). Warming increased the efflux by $74 \%$ (or around $25 \%$ per $^{\circ} \mathrm{C}$ ) (mean $6.11 \pm 3.07 \mathrm{SD} \mu \mathrm{mol} \mathrm{m}^{-2} \mathrm{~s}^{-1}$ ) compared with that of the unwarmed-trenched treatments (mean $\left.3.52 \pm 1.74 \mathrm{SD} \mu \mathrm{mol} \mathrm{m}{ }^{-2} \mathrm{~s}^{-1}\right)(p<0.001)$, while the control chambers obtained $4.98 \pm 2.44 \mathrm{SD} \mu \mathrm{mol} \mathrm{m}^{-2} \mathrm{~s}^{-1}$.

An exponential function described the relationship between the soil $\mathrm{CO}_{2}$ efflux and 10 soil temperature for each treatment using the hourly interval data for the entire study
period (Fig. 4). We also plotted the soil $\mathrm{CO}_{2}$ efflux averaged for every ${ }^{\circ} \mathrm{C}$ against the
soil temperature in order to evaluate clearly how soil $\mathrm{CO}_{2}$ efflux respond to every unit change in temperature (Fig. 5). However, if the total number of data points falling within particular ${ }^{\circ} \mathrm{C}$ is less than 30 , we excluded them from the determination of regression curves. The soil $\mathrm{CO}_{2}$ efflux of warmed-trenched and control chambers was higher than the unwarmed-trenched treatment at the same temperature.

To examine the sensitivity of soil $\mathrm{CO}_{2}$ efflux to soil temperature, we calculated basal respiration rate and temperature sensitivity $\left(Q_{10}\right)$ for the three treatments using, (1) all $1 \mathrm{~h}$ interval data (Fig. 4), and (2) averaged value for every ${ }^{\circ} \mathrm{C}$ (Fig. 5). For the first case, $Q_{10}$ values in unwarmed-trenched, warmed-trenched and control were 2.79, 2.74 , and 2.81, respectively. On the same manner, $Q_{10}$ values for the second case were $2.68,2.70$, and 2.65 , respectively. Although the averaging per ${ }^{\circ} \mathrm{C}$ slightly reduced their $Q_{10}$ values, the temperature sensitivity among all the treatments had only small difference for both cases. Meanwhile, basal respiration rate differs among each treatment with a consistently higher initial heterotrophic respiration in warmed-trenched chambers (1.21 and $1.24 \mu \mathrm{mol} \mathrm{m}^{-2} \mathrm{~s}^{-1}$ for the first and second cases, respectively) compared with unwarmed-trenched chambers $\left(0.93\right.$ and $0.99 \mu \mathrm{mol} \mathrm{m}^{-2} \mathrm{~s}^{-1}$, respectively). Control chambers were the highest (1.33 and $1.41 \mu \mathrm{mol} \mathrm{m}^{-2} \mathrm{~s}^{-1}$, respectively) owing to the contribution of root respiration.
BGD

$8,6415-6445,2011$

\section{Warming effect on soil heterotrophic respiration}

M. Aguilos et al.

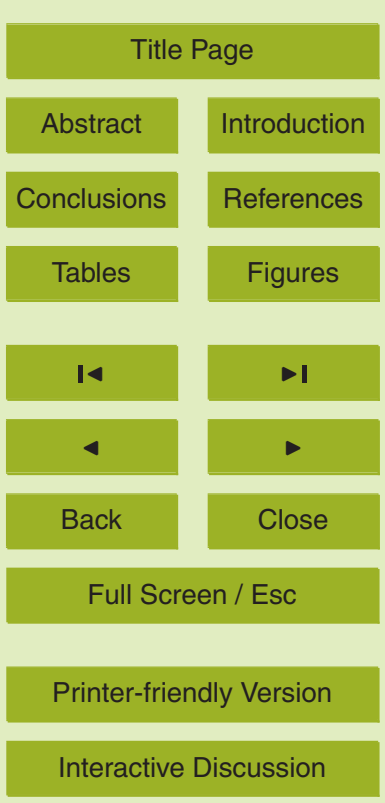


Inter-annual variation in temperature sensitivity for the unwarmed-trenched chambers showed slight difference within the three years with $Q_{10}$ equivalent to $2.73,2.84$, and 2.78 for 2007, 2008, and 2009, respectively (Fig. 6). Temperature sensitivity curves for warmed-trenched treatments showed that the efflux rates in 2008 and 2009 were 5 higher than that in 2007, while the reverse thing occurred in the control chambers wherein the efflux rate in 2008 and 2009 was lower than that in 2007, especially in higher temperature range. The $Q_{10}$ values for the warmed-trenched treatments in 2007,2008 , and 2009 were $2.71,2.85$, and 2.64, respectively, while control treatments had $3.09,2.93$, and 2.56 , respectively. It must be noted that the differences 10 in the $Q_{10}$ 's between unwarmed-trenched and warmed trenched treatments were very small in 2007 and 2008, hence the $Q_{10}$ obtained in 2009 had most likely caused the entire three year's $Q_{10}$ reduction in warmed-trenched treatment. On the other hand, inter-annual variation of basal respiration rate in 2007, 2008 and 2009 was 0.95, 0.93, and $0.94 \mu \mathrm{mol} \mathrm{m}{ }^{-2} \mathrm{~s}^{-1}$ for unwarmed-trenched; $1.12,1.11$, and $1.37 \mu \mathrm{mol} \mathrm{m}^{-2} \mathrm{~s}^{-1}$ for 15 warmed-trenched; and 1.27, 1.26, and $1.45 \mu \mathrm{mol} \mathrm{m}^{-2} \mathrm{~s}^{-1}$ for control (Fig. 6). Basal respiration rate in unwarmed-trenched treatment did not vary much within the 3-yr period, but the apparent increase in basal respiration rate in both warmed-trenched and control treatments can be observed in 2009. Considering the similar efflux rate at higher temperature range between 2008 and 2009, higher basal respiration rate in the warmed-trenched treatments in 2009 than in 2008 had caused the decrease of $Q_{10}$ in 2009. On the other hand, the decline of $Q_{10}$ in the control treatments in 2009 occurred not only because of its higher basal respiration rate but also due to a decrease in the efflux rate at higher temperature range.

The difference in soil $\mathrm{CO}_{2}$ efflux between unwarmed-trenched and control chambers showed that heterotrophic respiration contributed $71 \%$ of the total soil respiration and the remaining $29 \%$ was assumed to be the autotrophic respiration (Fig. 7). Autotrophic respiration peaked in advance (June to July) from that of heterotrophic respiration (August) in both 2008 and 2009. For over 20-month period, total soil respiration rate reached $2.74 \mathrm{kgC} \mathrm{m}^{-2}$ wherein $1.94 \mathrm{kgC} \mathrm{m}^{-2}$ of it had been contributed
BGD

8, 6415-6445, 2011

\section{Warming effect on soil heterotrophic respiration}

M. Aguilos et al.

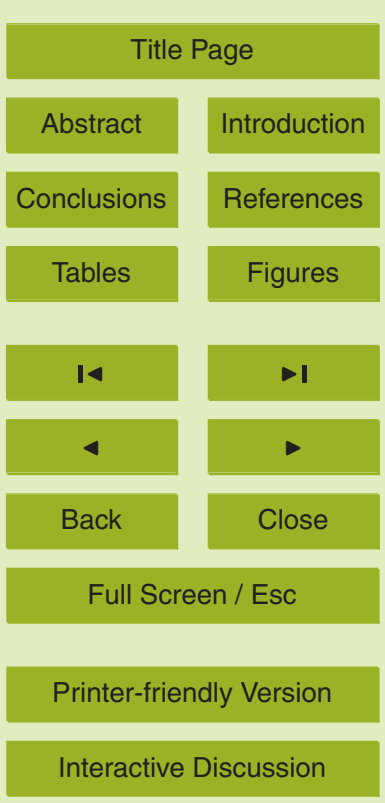


by heterotrophic respiration. Calculating for an equal period of measurement from 22 April to 19 November for both 2008 and 2009 showed that total soil respiration rate dropped from $1.20 \mathrm{kgC} \mathrm{m}^{-2}$ in 2008 to $1.13 \mathrm{kgC} \mathrm{m}^{-2}$ in 2009 while soil heterotrophic respiration decreased from $0.86 \mathrm{kgC} \mathrm{m}^{-2}$ in 2008 down to $0.81 \mathrm{kgC} \mathrm{m}^{-2}$ in 2009 . A 5 higher average soil temperature in 2008 (15.5 and $15.6^{\circ} \mathrm{C}$ for control and unwarmedtrenched treatment, respectively) than that in $2009\left(14.8\right.$ and $15.0^{\circ} \mathrm{C}$, respectively) was observed from June to September, and this could cause the decrease in the soil respiration rates in 2009. The rate of decrease in the total soil respiration from 2008 to $2009\left(0.07 \mathrm{kgC} \mathrm{m}^{-2}\right)$ was primarily driven by the decrease in the soil heterotrophic 0 respiration $\left(0.05 \mathrm{kgC} \mathrm{m}^{-2}\right)$.

When we assume the non-growing season respiration rates to obtain an annual respiration rates by using the soil temperature data throughout the study period (Fig. 1) and temperature-respiration relationships (Fig. 6), the annual total and heterotrophic respirations were 1.43 and $1.03 \mathrm{kgC} \mathrm{m}^{-2}$, respectively, in 2008 , and 1.39 and $0.98 \mathrm{kgC} \mathrm{m}^{-2}$ in 2009. Additional rates were 16 to $19 \%$ of the annual total respiration rates and did not alter the growing season inter-annual tendencies.

Given the $Q_{10}$ values of 2.81 and 2.79 for both control (representing the total soil respiration) and unwarmed-trenched (for heterotrophic respiration) treatments, estimated autotrophic respiration $Q_{10}$ value was 2.75 . This was obtained by subtracting the hourly respiration rates in unwarmed-trenched chambers from that of the control chambers during the entire study period. The difference was used to establish a regression line that determines the $Q_{10}$ value of autotrophic respiration.

\subsection{Effect of soil moisture on soil $\mathrm{CO}_{2}$ efflux}

Although the soil water content (SWC) of the warmed-trenched chambers was lower than those of the unwarmed-trenched and control chambers, the absolute values were always high for the three treatments and no relationship was observed between normalized $\mathrm{CO}_{2}$ efflux and the SWC. This trend did not change even in the case of using
BGD

$8,6415-6445,2011$

\section{Warming effect on soil heterotrophic respiration}

M. Aguilos et al.

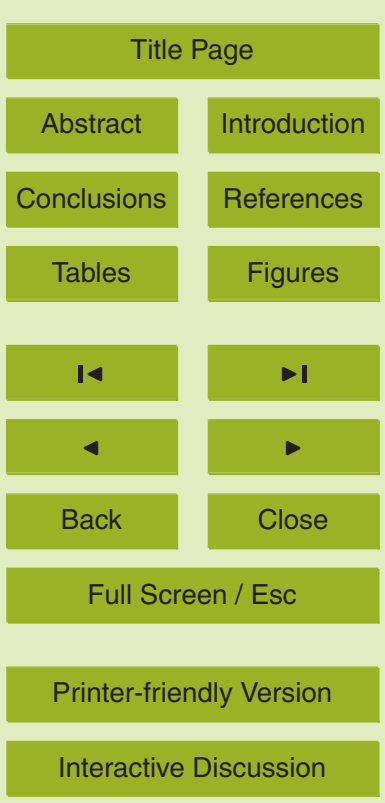


monthly averaged data (Fig. 8), which simply implies that soil moisture is not a limiting factor in this study site.

BGD

$8,6415-6445,2011$

\section{Discussion}

\subsection{Warming effect on soil heterotrophic respiration}

5 Our warming experiment increased heterotrophic respiration rate by $74 \%$ which has proven our assumption that elevated temperature would stimulate heterotrophic respiration. This increase is higher than the work of Melillo et al. (2002) $\left(5^{\circ} \mathrm{C}\right.$ increase in the soil temperature in an even-aged mixed forest) who showed a $28 \%$ increase in soil respiration rate over the first 6 yr. Similarly, Rustad et al. (2001) synthesized the soil 10 respiration response to 2 to $5 \mathrm{yr}$ experimental warming $\left(1.5\right.$ to $6.0^{\circ} \mathrm{C}$ increase in the soil temperature) conducted at 7 forested ecosystems and reported 7 to $46 \%$ rise in soil $\mathrm{CO}_{2}$ efflux. In addition, Niinistö et al. (2004) reported 27 to $43 \%$ rise in soil $\mathrm{CO}_{2}$ efflux by a 4-yr warming experiment ( 3 to $6^{\circ} \mathrm{C}$ increase in the air temperature) in a 20year-old Scots pine forest, and Bronson et al. (2008) revealed 24 and $11 \%$ increase in soil $\mathrm{CO}_{2}$ efflux at first and second year, respectively, of the warming experiment $\left(5^{\circ} \mathrm{C}\right.$ increase in the soil temperature) in a Black spruce forest. Schindlbacher et al. (2009) reported 39 and $45 \%$ increase in the soil heterotrophic respiration rate at first and second year, respectively, of the soil warming $\left(4^{\circ} \mathrm{C}\right.$ increase in the soil temperature) in a mature forest dominated by Norway spruce.

In addition to the high increasing ratio of heterotrophic respiration caused by soil warming of this study, we could not observe distinct decrease in the warming effect on the respiration rate within three years of the study period, although the previous studies pointed out a decrease in the warming effect after several years of the experiment caused by depletion of substrate availability or acclimation of decomposer community. Melillo et al. (2002) reported decrease in the warming effect after $6 \mathrm{yr}$ of warming and on the 10th year soil respiration rate showed no significant response. Rustad et

\section{Warming effect on soil heterotrophic respiration}

M. Aguilos et al.

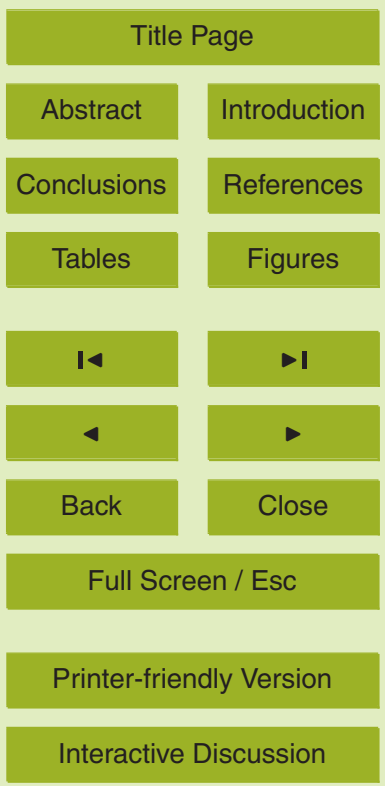

Interactive Discussion 
al. (2001) suggested that the significant positive effect of warming on soil respiration rate was observed during the initial 3 years, and no significant effect in later years. Bronson et al. (2008) reported that the increase in soil $\mathrm{CO}_{2}$ efflux by soil warming was diminished over time within two years of the warming experiment. Strömgren 5 (2001) concluded that the rates of soil $\mathrm{CO}_{2}$ efflux on heated plots were not significantly different from the control plots in the fifth year of warming.

The high increasing ratio throughout the $3 \mathrm{yr}$ of our warming experiment could be attributed to two specific environmental factors in our study site, i.e. large substrate availability and high soil water content. Our study site had been a peatland and was 10 drained ca. $30 \mathrm{yr}$ ago for tree plantation, so there is very thick surface organic layer in the soil and no distinct soil stratification was observed. Assuming that surface $30 \mathrm{~cm}$ soil layer had similar carbon content with that in the surface $5 \mathrm{~cm}$ layer, the carbon content became $17.2 \mathrm{kgC} \mathrm{m}^{-2}$. This value is the same with the mean value for the Japanese peatland soils at surface $30 \mathrm{~cm}$ layer $\left(17.2 \mathrm{kgC} \mathrm{m}^{-2}\right)$ reported by Morisada 15 et al. (2004) or much higher than the mean global estimate of $11.3 \mathrm{kgC} \mathrm{m}^{-2}$ at surface $100 \mathrm{~cm}$ layer (Sombroek et al., 1993). The soil heterotrophic respiration rate of $1.94 \mathrm{kgC} \mathrm{m}^{-2}$ over the 20 -month study period accounts for the $11 \%$ remaining soil carbon content at surface $30 \mathrm{~cm}$ soil layer and would not cause serious depletion of available substrate. In addition, it must be noted that litterfall had continuously sup20 plied carbon to the soil. Although we do not have observed data to support this but a study around our site with the same species composition obtained a litterfall rate of $0.13 \mathrm{kgC} \mathrm{m}^{-2} \mathrm{yr}^{-1}$ (Fukuzawa, 2007). Assuming that the same amount of litterfall had been supplied in our study area, a rate of $0.39 \mathrm{kgC} \mathrm{m}^{-2}$ for $3 \mathrm{yr}$ would have been added to the prevailing soil carbon content of $17.2 \mathrm{kgC} \mathrm{m}^{-2}$, thus reducing the impact of soil 25 heterotrophic emission. In addition, the soil water content had kept constantly high at more than $30 \%$ throughout the study period even at the heated plot, thus microbial activities would not be stressed by soil water deficit.

Supporting our consideration, repeated soil inventories in England and Wales over the last $25 \mathrm{yr}$ have shown that peat soils and bogs lost $C$ at a faster rate than upland
BGD

$8,6415-6445,2011$

\section{Warming effect on soil heterotrophic respiration}

M. Aguilos et al.

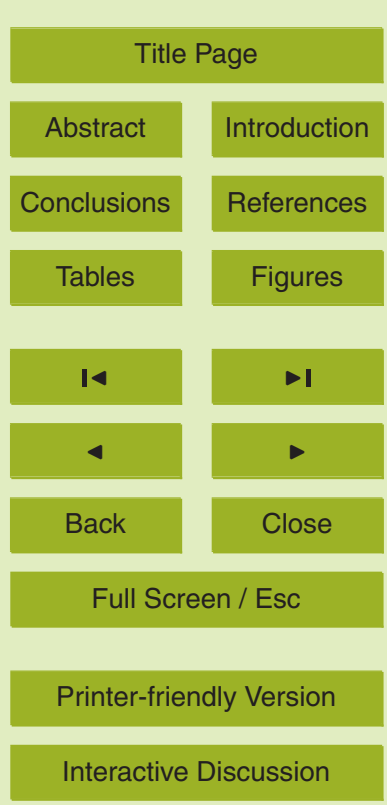


soils (Bellamy et al., 2005). In addition, Dorrepaal et al. (2009) revealed that approximately $1{ }^{\circ} \mathrm{C}$ warming accelerated total ecosystem respiration rates on average by $60 \%$ in spring and by $52 \%$ in summer in a subarctic peatland and that this effect was sustained for at least eight years. They also found that at least $69 \%$ of the increase 5 in respiration rate originated from carbon in subsurface peat towards the bottom (25 to $50 \mathrm{~cm}$ ) of the active layer above the permafrost. Ise et al. (2008) reported high sensitivity of peat decomposition to warming temperature in boreal old black spruce and fen sites of the Northern Study Area of the Boreal Ecosystem-Atmosphere Study (BOREAS), and their simulation revealed that experimental warming of $4{ }^{\circ} \mathrm{C}$ causes a $1040 \%$ loss of soil organic carbon from the shallow peat and $86 \%$ loss from the deep peat, concluding that peatlands will quickly respond to the expected warming in this century by losing labile soil organic carbon during dry periods. However, in any case, our results were obtained only from 3 yr experiment, although Strömgren (2001), Rustad et al. (2001), and Melillo et al. (2002) reported depression of the warming effect 15 after at least $3 \mathrm{yr}$ of the experiment. These results have challenged us to continue our work and assess whether this effect will be sustained beyond three years.

\subsection{Temperature sensitivity}

Our warming experiment slightly decreased $Q_{10}$, when the value was determined using hourly data (2.79 and 2.74 for unwarmed and warmed treatments, respectively), however the opposite result was obtained when we used averaged efflux rate for every ${ }^{\circ} \mathrm{C}$ (2.68 and 2.70). The difference between treatments was small for both cases, thus we can conclude that soil warming did not cause the significant change in the $Q_{10}$ value. On the other hand, we observed 25 (hourly data) and 30 (bin average for every ${ }^{\circ} \mathrm{C}$ ) $\%$ increase in the basal respiration rate (efflux rate at $0^{\circ} \mathrm{C}$ ) by soil warming throughout

the three years. This trend was also true for the value determined each year. Reductions in the $Q_{10}$ under induced temperature were observed in a tallgrass prairie (Luo et al., 2001), suggesting acclimation of respiration to climate warming and/or alteration of substrate supply. Strömgen (2001) and Bronson (2008) also reported a lower $Q_{10}$ 's for
BGD

8, 6415-6445, 2011

\section{Warming effect on soil heterotrophic respiration}

M. Aguilos et al.

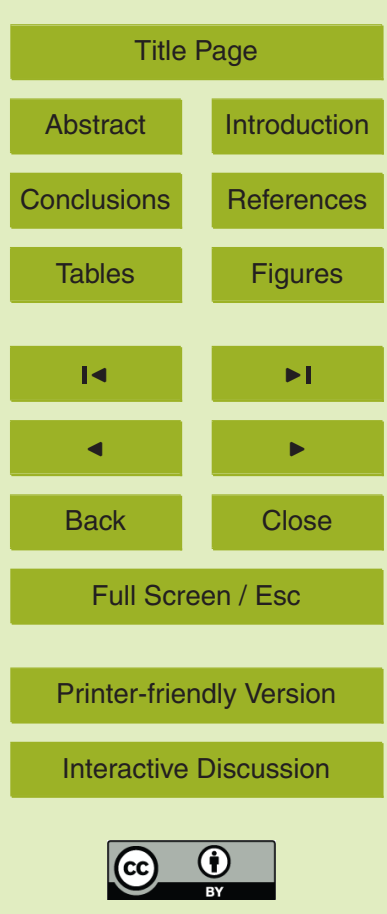


the heated than the control treatments. On the other hand, Niinistö et al. (2004) could not find significant difference in the $Q_{10}$ values between warming and control treatments during the four years experiment (although $Q_{10}$ was smaller for the warming plots than that for control), and reported significant difference in the basal respiration

5 rate in the final year of the experiment, which supports our results. Large substrate availability and high soil moisture condition in our study site helped in keeping a high temperature sensitivity during the whole three years of the experiment, and rather increased the soil respiration rate at low temperature range. The large enhancement in soil heterotrophic respiration rate $(74 \%)$ was realized by the increase in temperature 10 by $3^{\circ} \mathrm{C}$ without change in the $Q_{10}\left(36 \%\right.$ increase for $\left.Q_{10}=2.8\right)$ and increase in the basal respiration rate (25 to $30 \%$ ). It is difficult to explain the reason for the increase in the basal respiration rate by soil warming, however, enhancement of the soil microbial activities or change in the composition would be attributed. Further investigation is still needed to verify these accounts.

15 Our results (stimulation in basal respiration rate without depletion of $Q_{10}$ ) suggest a greater carbon release and a weakening carbon sequestration potential in future warmer climate for ecosystems with high substrate availability and soil moisture, and prediction model with no change in the basal respiration rate would cause an underestimation of carbon release from the soil to the atmosphere in future warmer environment. Gorham (1991) estimated that total release of carbon by drainage of boreal and subarctic peatlands could be 8.5 to $42 \mathrm{TgC} \mathrm{yr}^{-1}$. Accordingly, $74 \%$ increase in soil heterotrophic respiration rate would correspond to an increased release of 6 to $31 \mathrm{TgC} \mathrm{yr}^{-1}$. This is $10 \%$ of Japan's current industrial $\mathrm{CO}_{2}$ emission of $330 \mathrm{Tg} \mathrm{C} \mathrm{yr}^{-1}$ in 2008 (GIO and CGER- NIES, 2010), and could provide a strong positive feedback to 25 global atmospheric $\mathrm{CO}_{2}$ concentrations and, consequently, warming.

\subsection{Contribution of heterotrophic respiration to the total soil respiration}

The temperature-response curve of control (total soil respiration) is higher than the unwarmed-trenched (heterotrophic respiration) owing to the presence of live and/or
BGD

$8,6415-6445,2011$

\section{Warming effect on soil heterotrophic respiration}

M. Aguilos et al.

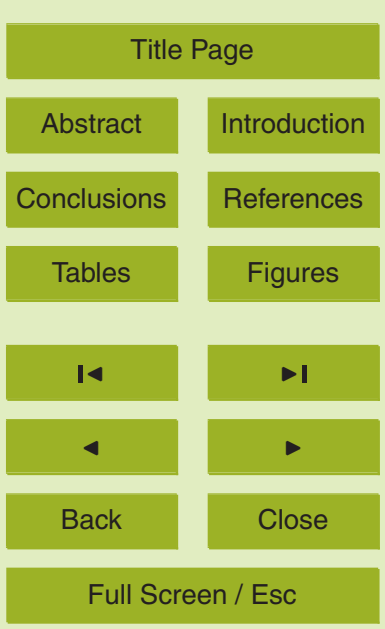

Printer-friendly Version

Interactive Discussion 
decomposing roots compared to the root-lacking trenched chambers. Our result showed that heterotrophic respiration rate (not associated with warming) governs the total soil respiration rate given its $71 \%$ contribution. Those who agree with this result include: $67 \%$ for a mixed hardwood forest in Massachusetts (Bowden et al., 1993);

$577 \%$ for a lowland old-growth beech (Nothofacus) in New Zealand (Tate et al., 1993); $>70 \%$ for Picea abies stands in Northeast Bavaria, Germany (Buchmann, 2000); and 56 to $69 \%$ for a subalpine forest dominated by lodgepole pine (Pinus contorta) trees in Niwot Ridge, Colorado (Scott-Denton et al., 2006). On the other hand, root respiratory contribution in our case only held the $29 \%$ fraction of the total soil respiration, although 10 this is lower than those of previous studies reporting $90 \%$ for a oak-hornbeam forest in Belgium (Thierron and Laudelout, 1996); $54 \%$ for a boreal forest in Saskatchewwan, Canada (Uchida et al., 1998); 52 to $56 \%$ for a boreal Scots pine (Pinus sylvestris L.) forest (Högberg et al., 2001); and $78 \%$ for a mixed mountain forest in Switzerland (Ruehr and Buchmann, 2010). Temperature sensitivity also showed that root respira15 tion had almost similar $Q_{10}$ value (2.75) with 2.79 for heterotrophic respiration, thus disputing the notions made by Boone et al. (1998), Grogan and Jonasson (2005), and Ruehr and Buchmann (2010) who explained that root respiration was more temperature sensitive than bulk soil respiration.

\section{Conclusions}

20 The large positive increase $(74 \%)$ in soil heterotrophic respiration with $3^{\circ} \mathrm{C}$ elevated soil temperature in our study suggests that warming accelerates a loss of carbon from soils in forested peatlands more seriously than other upland soils. But whether this response lasts will be revealed by further monitoring. Soil warming increased the basal respiration rate with $Q_{10}$ remained unchanged, thus if we predict the soil heterotrophic respiration rate in future warmer environment using the current relationship between soil temperature and heterotrophic respiration, the rate can be underestimated.

\section{BGD}

8, 6415-6445, 2011

\section{Warming effect on soil heterotrophic respiration}

M. Aguilos et al.

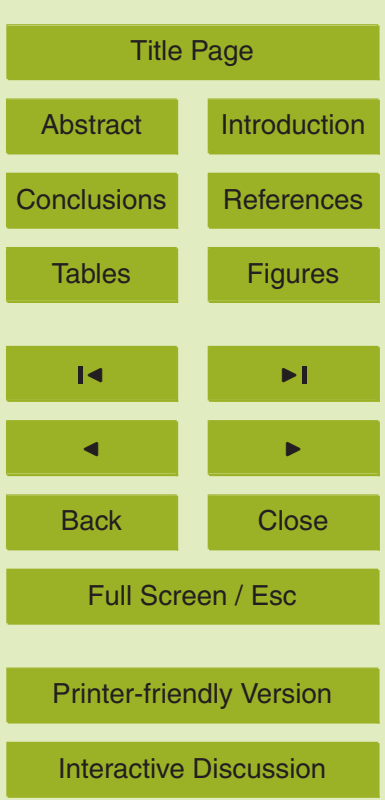


Acknowledgements. This research was financially supported by Global Environment Research Fund (B-073) from Ministry of the Environment, Grants-in-Aid for Scientific Research (no. 22310019) from the Japanese Ministry of Education, Culture, Sports, Science and Technology, and A3 Foresight Program (CarboEastAsia) by the Japan Society for the Promotion of 5 Sciences. We thank the staff of Teshio Experimental Forest for their support.

\section{References}

Bellamy, P. H., Loveland, P. J., Bradley, R. I., Lark, R. M., and Kirk, G. J. D.: Carbon losses from all soils across England and Wales 1978-2003, Nature, 437, 245-248, doi:10.1038/nature04038, 2005.

Bond-Lamberty, B. and Thomson, A.: Temperature-associated increases in the global soil respiration record, Nature, 464, 579-582, doi:10.1038/nature08930, 2010.

Boone, R. D., Nadelhoffer, K. J., Canary, J. D., and Kaye, J. P.: Roots exert a strong influence on the temperature sensitivity of soil respiration, Nature, 396, 570-572, 1998.

Bowden, R. D., Nadelhoffer, K. J., Boone, R. D., Melillo, J. M., and Garrison, J. B.: Contributions of aboveground litter, belowground litter, and root respiration to total soil respiration in a temperature mixed hardwood forest, Can. J. For. Res., 23, 1402-1407, 1993.

Bronson, D. R., Gower, S. T., Tanner, M., Linder, S., and Van Herk, I.: Response of soil surface $\mathrm{CO}_{2}$ flux in a boreal forest to ecosystem warming, Global Change Biol., 14, 856-867, doi:10.1111/j.1365-2486.2007.01508.x, 2008.

Buchmann, N.: Biotic and abiotic factors controlling soil respiration rates in Picea abies stands, Soil Biol. Biochem., 32, 1625-1635, doi:10.1016/S0038-0717(00)00077-8, 2000.

Cox, P. M., Betts, R. A., Jones, C. D., Spall, S. A., and Totterdell, I. J.: Acceleration of global warming due to carbon-cycle feedbacks in a coupled climate model, Nature, 408, 184-187, doi:10.1038/35041539, 2000.

25 Davidson, E. A. and Janssens, I. A.: Temperature sensitivity of soil carbon decomposition and feedbacks to climate change, Nature, 440, 165-173, doi:10.1038/nature04514, 2006.

Davidson, E. A., Janssens, I. A., and Luo, Y.: On the variability of respiration in terrestrial ecosystems: Moving beyond $Q_{10}$, Global Change Biol., 12, 154-164, doi:10.1111/j.13652486.2005.01065.x, 2006.

Dorrepaal, E., Toet, S., van Longtestijn, R. S. P., Swart, E., van de Weg, M. J., Callaghan, T. V.,

\section{BGD}

$8,6415-6445,2011$

\section{Warming effect on soil heterotrophic respiration}

M. Aguilos et al.

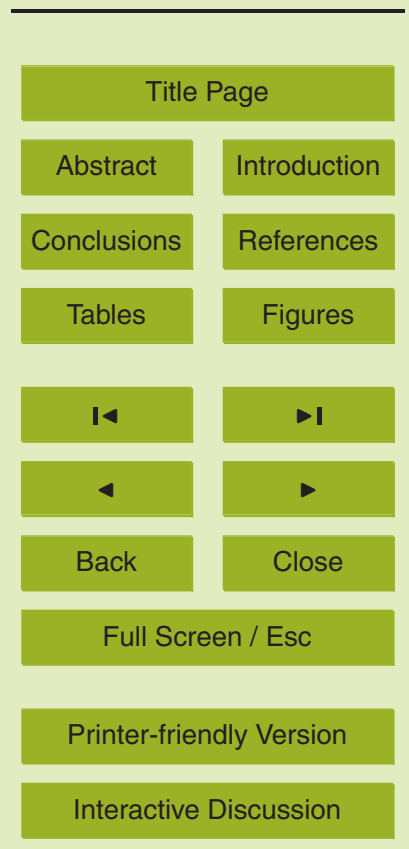


and Aerts, R.: Carbon respiration from subsurface peat accelerated by climate warming in the subarctic, Nature, 460, 616-619, doi:10.1038/nature08216, 2009.

Friedlingstein, P., Cox, P., Betts, R., Bopp, L., Von Bloh, W., Brovkin, V., Cadule, P., Doney, S., Eby, M., Fung, I., Bala, G., John, J., Jones, C., Joos, F., Kato, T., Kawamiya, M., Knorr, W., Lindsay, K., Matthews, H. D., Raddatz, T., Rayner, P., Reick, C., Roeckner, E., Schnitzler, K. G., Schnur, R., Strassmann, K., Weaver, A. J., Yoshikawa, C., and Zeng, N.: Climate-carbon cycle feedback analysis: Results from the C4MIP model intercomparison, J. Climate, 19, 3337-3353, 2006.

Fukuzawa, K.: The role of fine roots in carbon and nitrogen dynamics in a cool-temperate forest covered with Sasa dwarf bamboo, PhD Thesis, Hokkaido University, 104 pp., 2007 (in Japanese).

Gorham, E.: Northern peatlands: Role in the carbon cycle and probable responses to climatic warming, Ecol. Appl., 182-195, 1991.

Greenhouse Gas Inventory Office of Japan (GIO) and Center for Global Environmental Research (CGER)-National Institute for Environmental Studies (NIES) (eds): National greenhouse gas inventory report of JAPAN, CGER-report, CGER-I093-2010, Center for Global Environmental Research, Tsukuba, 2010.

Grogan, P. and Jonasson, S.: Temperature and substrate controls on intra-annual variation in ecosystem respiration in two subarctic vegetation types, Global Change Biol., 11, 465-475, doi:10.1111/j.1365-2486.2005.00912.x, 2005.

Högberg, P., Nordgren, A., Buchmann, N., Taylor, A. F. S., Ekblad, A., Högberg, M. N., Nyberg, G., Ottosson-Löfvenius, M., and Read D. J.: Large-scale forest girdling shows that current photosynthesis drives soil respiration, Nature, 411, 789-792, doi:10.1038/35081058, 2001.

IPCC: Climate Change 2007: The physical Science Basis. Contribution of Working Group I to the Fourth Assessment Report of the Intergovernmental Panel on Climate Change, edited by: Solomon, S., Qin, D., Manning, M., Chen, Z., Marquis, M., Averyt, K. B., Tignor, M., and Miller, H. L., Cambridge University Press, Cambridge, UK and New York, NY, USA, 996 pp., 2007.

Ise, T., Dunn, A. L., Wofsy, S. C., and Moorcroft, P. R.: High sensitivity of peat decompo30 sition to climate change through water-table feedback, Nature Geoscience, 1, 763-766, doi:10.1038/ngeo331, 2008.

Jenkinson, D. S., Adams, D. E., and Wild, A.: Model estimates of $\mathrm{CO}_{2}$ emissions from soil in response to global warming, Nature, 351, 304-306, doi:10.1038/351304a0, 1991.
BGD

$8,6415-6445,2011$

\section{Warming effect on soil heterotrophic respiration}

M. Aguilos et al.

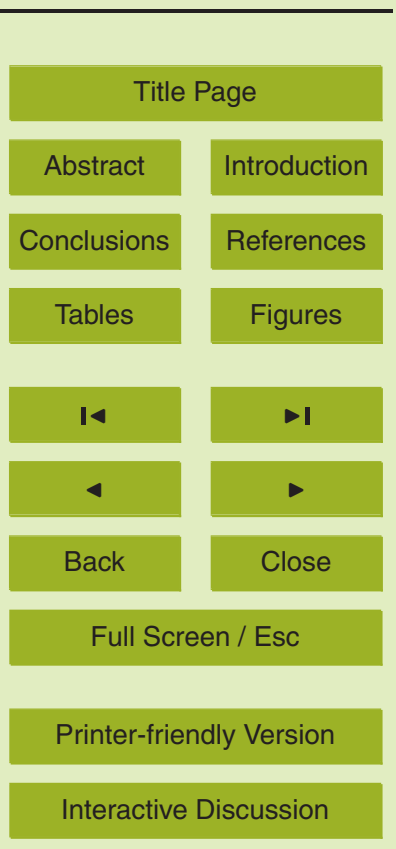


Kirschbaum, M. U. F.: The temperature dependence of soil organic matter decomposition, and the effect of global warming on soil organic-C storage, Soil Biol. Biochem., 27, 753-760, doi:10.1016/0038-0717(94)00242-S, 1995.

Knorr, W., Prentice, I. C., House, J. I., and Holland, E. A.: Long-term sensitivity of soil carbon turnover to warming, Nature, 433, 298-301, doi:10.1038/nature03226, 2005

Liang, N., Inoue, G., and Fujinuma, Y.: A multichannel automated chamber system for continuous measurement of forest soil $\mathrm{CO}_{2}$ efflux, Tree Physiol., 23, 825-832, doi:10.1093/treephys/23.12.825, 2003.

Liang, N., Nakadai, T., Hirano, T., Qu, L., Koike, T., Fujinuma, Y., and Inoue, G.: In situ comparison of four approaches to estimating soil $\mathrm{CO}_{2}$ efflux in a northern larch (Larix kaempferi Sarg.) forest, Agric. For. Meteorol., 123, 97-117, 2004.

Liang, N., Hirano, T., Zheng, Z.-M., Tang, J., and Fujinuma, Y.: Soil $\mathrm{CO}_{2}$ efflux of a larch forest in northern Japan, Biogeosciences, 7, 3447-3457, doi:10.5194/bg-7-3447-2010, 2010.

Lloyd, J. and Taylor, J. A.: On the temperature dependence of soil respiration, Funct. Ecol., 8, 315-323, 1994.

Luo, Y., Wan, S., Hui, D., and Wallace, L. L.: Acclimatization of soil respiration to warming in a tall grass prairie, Nature, 413, 622-625, doi:10.1038/35098065, 2001.

Melillo, J. M., Steudler, P. A., Aber, J. D., Newkirk, K., Lux, H., Bowles, F. P., Catricala, C., Magill, A., Ahrens, T., and Morrisseau, S.: Soil warming and carbon-cycle feedbacks to the

20 climate system, Science, 298, 2173-2176, doi:10.1126/science. 1074153, 2002.

Morisada, K., Ono, K., and Kanomata, H.: Organic carbon stock in forest soils in Japan, Geoderma, 119, 21-32, doi:10.1016/S0016-7061(03)00220-9, 2004.

Niinistö, S. M., Silvola, J., and Kellomäki, S.: Soil $\mathrm{CO}_{2}$ efflux in a boreal pine forest under atmospheric $\mathrm{CO}_{2}$ enrichment and air warming, Global Change Biol., 10, 1363-1376, doi:10.1111/j.1365-2486.2004.00799.x, 2004.

Ruehr, N. K. and Buchmann, N.: Soil respiration fluxes in a temperate mixed forest: seasonality and temperature sensitivities differ among microbial and root-rhizosphere respiration, Tree Physiol., 30, 165-176, doi:10.1093/treephys/tpp106, 2010.

Rustad, L. E., Campbell, J. L., Marion, G. M., Norby, R. J., Mitchell, M. J., Hartley, A. E., Cornelissen, J. H. C., Gurevitch, J., and GCTE-NEWS: A meta-analysis of the response of soil respiration, net nitrogen mineralization, and aboveground plant growth to experimental ecosystem warming, Oecologia, 126, 543-562, doi:10.1007/s004420000544, 2001.

Scott-Denton, L. E., Rosenstiel, T. N., and Monson, R. K.: Differential controls by climate

BGD

8, 6415-6445, 2011

\section{Warming effect on soil heterotrophic respiration}

M. Aguilos et al.

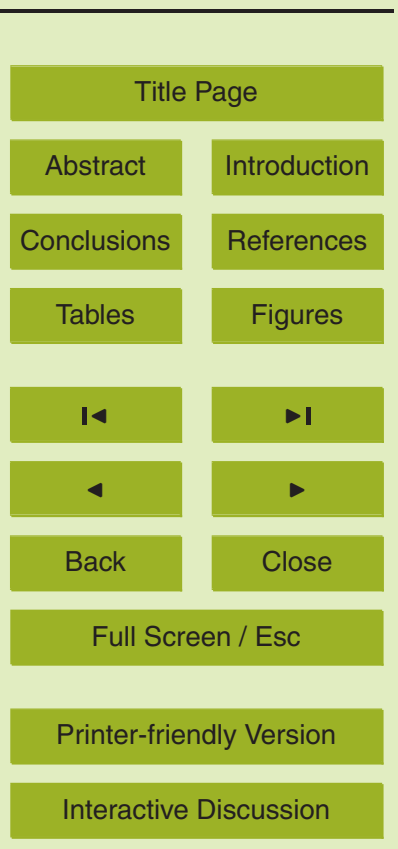


and substrate over the heterotrophic and rhizospheric components of soil respiration, Global Change Biol., 12, 205-216, doi:10.1111/j.1365-2486.2005.01064.x, 2006.

Schindlbacher, A., Zechmeister-Boltenstern, S., and Jandl, R.: Carbon losses due to soil warming: Do autotrophic and heterotrophic soil respiration respond equally? Global Change Biol., 15, 901-913, doi:10.1111/j.1365-2486.2008.01757.x, 2009.

Sombroek, W. G., Nachtergaele, F. O., and Hebel, A.: Amounts, dynamics and sequestering of carbon in tropical and subtropical soils, AMBIO, 22, 417-426, 1993.

Strömgren, M.: Soil-surface $\mathrm{CO}_{2}$ flux and growth in a boreal Norway spruce stand, Effects of soil warming and nutrition, Doctoral thesis, Acta Universitatia Agriculturae Sueciae, Silvestria 220, Swedish University of Agricultural Sciences, Uppsala, ISBN 91-576-6304-1, 44 pp., 2001.

Takagi, K., Fukuzawa, K., Liang, N., Kayama, M., Nomura, M., Hojyo, H., Sugata, S., Shibata, H., Fukazawa, T., Takahashi, Y., Nakaji, T., Oguma, H., Mano, M., Akibayashi, Y., Murayama, T., Koike, T., Sasa, K., and Fujinuma, Y.: Change in $\mathrm{CO}_{2}$ balance under a series of forestry activities in a cool-temperate mixed forest with dense undergrowth, Global Change Biol., 15, 1275-1288, doi:10.1111/j.1365-2486.2008.01795.x, 2009.

Tate, K. R., Ross, D. J., O'Brien, B. J., and Kelliher, F. M.: Carbon storage and turnover, and respiratory activity, in the litter and soil of an old-growth southern beech (nothofagus) forest, Soil Biol. Biochem., 25, 1601-1612, doi:10.1016/0038-0717(93)90016-5, 1993.

Thierron, V. and Laudelout, $\mathrm{H}$.: Contribution of root respiration to total $\mathrm{CO}_{2}$ efflux from the soil of a deciduous forest, Can. J. For. Res., 26, 1142-1148, doi:10.1139/x26-127, 1996.

Uchida, M., Nakatsubo, T., Horikoshi, T., and Nakane, K.: Contribution of micro-organisms to the carbon dynamics in black spruce (Picea mariana) forest soil in Canada, Ecol. Res., 13, 17-26, doi:10.1046/j.1440-1703.1998.00244.x, 1998.

\section{BGD}

$8,6415-6445,2011$

\section{Warming effect on soil heterotrophic respiration}

M. Aguilos et al.

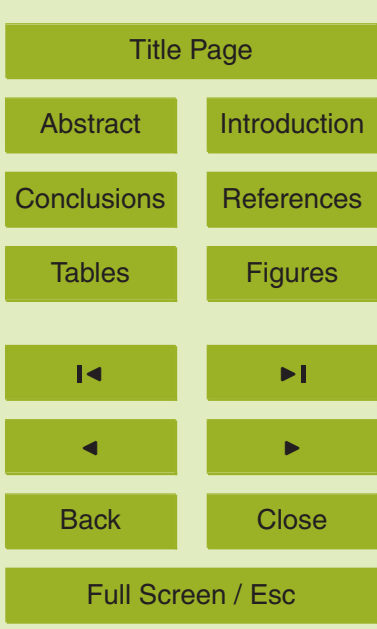

Printer-friendly Version

Interactive Discussion 
BGD

$8,6415-6445,2011$

\section{Warming effect on soil heterotrophic respiration}

M. Aguilos et al.

Table 1. Parameters and average soil $\mathrm{CO}_{2}$ efflux with different treatments.

\begin{tabular}{|c|c|c|c|c|c|c|c|c|c|}
\hline & \multicolumn{3}{|c|}{ Unwarmed-trenched } & \multicolumn{3}{|c|}{ Warmed-trenched } & \multicolumn{3}{|c|}{ Control } \\
\hline & $R_{0}$ & $Q_{10}$ & $R_{\text {mean }}$ & $R_{0}$ & $Q_{10}$ & $R_{\text {mean }}$ & $R_{0}$ & $Q_{10}$ & $R_{\text {mean }}$ \\
\hline 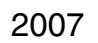 & 0.95 & 2.73 & 2. & 1.12 & 2.71 & $4.67 \pm 2$ & 1.27 & 3.09 & $4.46=$ \\
\hline 200 & 0.93 & 2.84 & 3.5 & 1.11 & 2.85 & $5 . \varepsilon$ & 1.26 & 2.93 & 60 \\
\hline 2009 & 0.94 & 2.78 & $3.71 \pm 1.63$ & 1.37 & 2.64 & $6.91 \pm 3.05$ & 1.45 & 2.56 & $5.18 \pm 2.10$ \\
\hline
\end{tabular}

$R_{0}$ and $R_{\text {mean }}$ are basal respiration rate at $0{ }^{\circ} \mathrm{C}$ and mean soil $\mathrm{CO}_{2}$ efflux during observation period, respectively. $R_{0}$ and $Q_{10}$ are evaluated using bin averages of efflux rates per every ${ }^{\circ} \mathrm{C}$ (see Fig. 6). $R_{\text {mean }}$ values are shown with the S.D.

\section{Title Page}

Abstract

Introduction

Conclusions

References

Tables

Figures

14

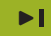

4

Back

Close

\section{Full Screen / Esc}

Printer-friendly Version

Interactive Discussion 


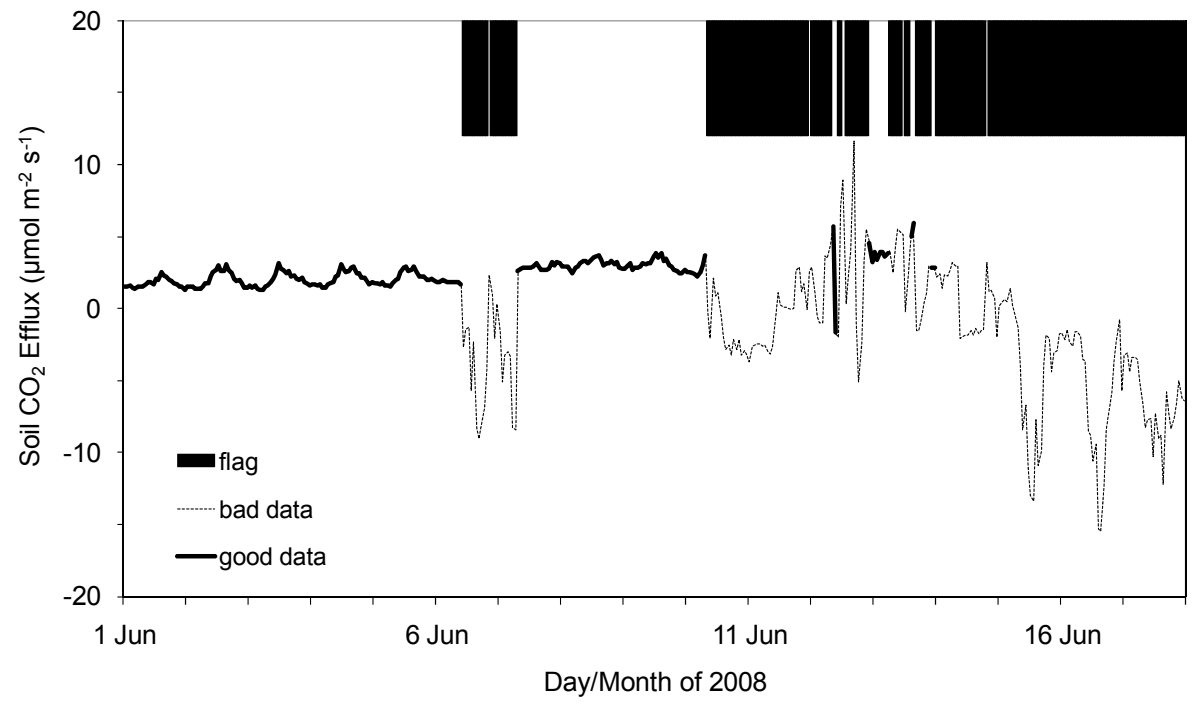

\section{BGD}

8, 6415-6445, 2011

\section{Warming effect on soil heterotrophic respiration}

M. Aguilos et al.

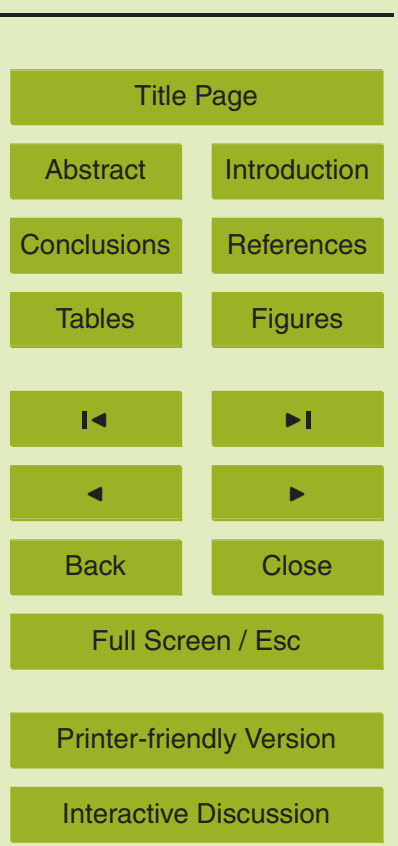




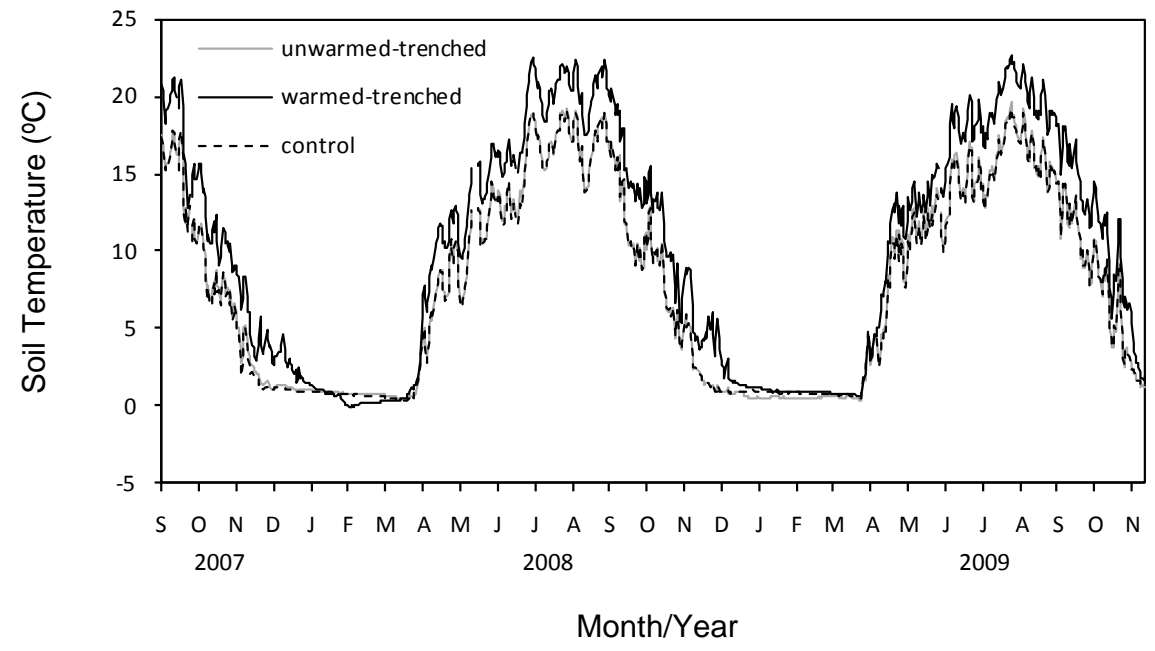

Fig. 2. Inter-annual variation of soil temperature in unwarmed-trenched, warmed-trenched, and control during the study period in 2007-2009. All data are daily averages.
BGD

8, 6415-6445, 2011

\section{Warming effect on soil heterotrophic respiration}

M. Aguilos et al.

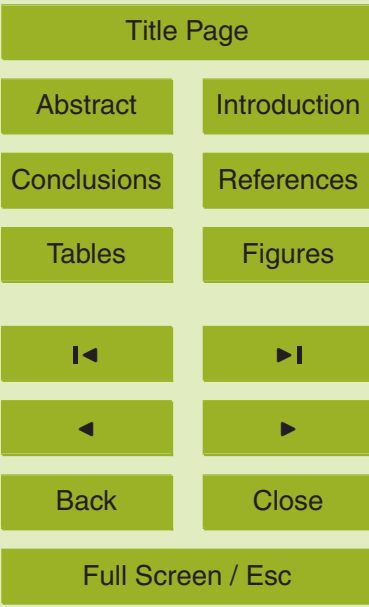

Printer-friendly Version

Interactive Discussion 


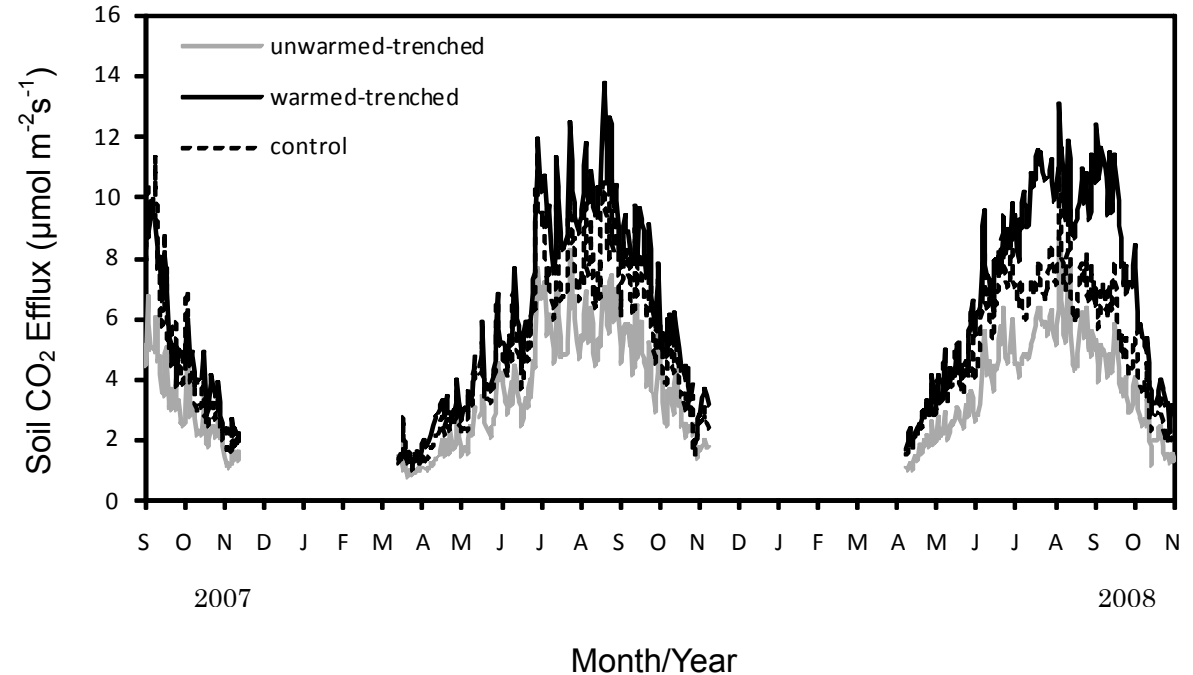

Fig. 3. Interannual variation in soil $\mathrm{CO}_{2}$ efflux during the snow-free seasons in 2007-2009.

\section{BGD}

8, 6415-6445, 2011

\section{Warming effect on soil heterotrophic respiration}

M. Aguilos et al.

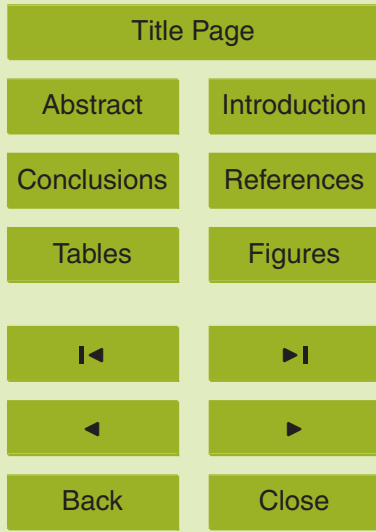

Full Screen / Esc

Printer-friendly Version

Interactive Discussion 


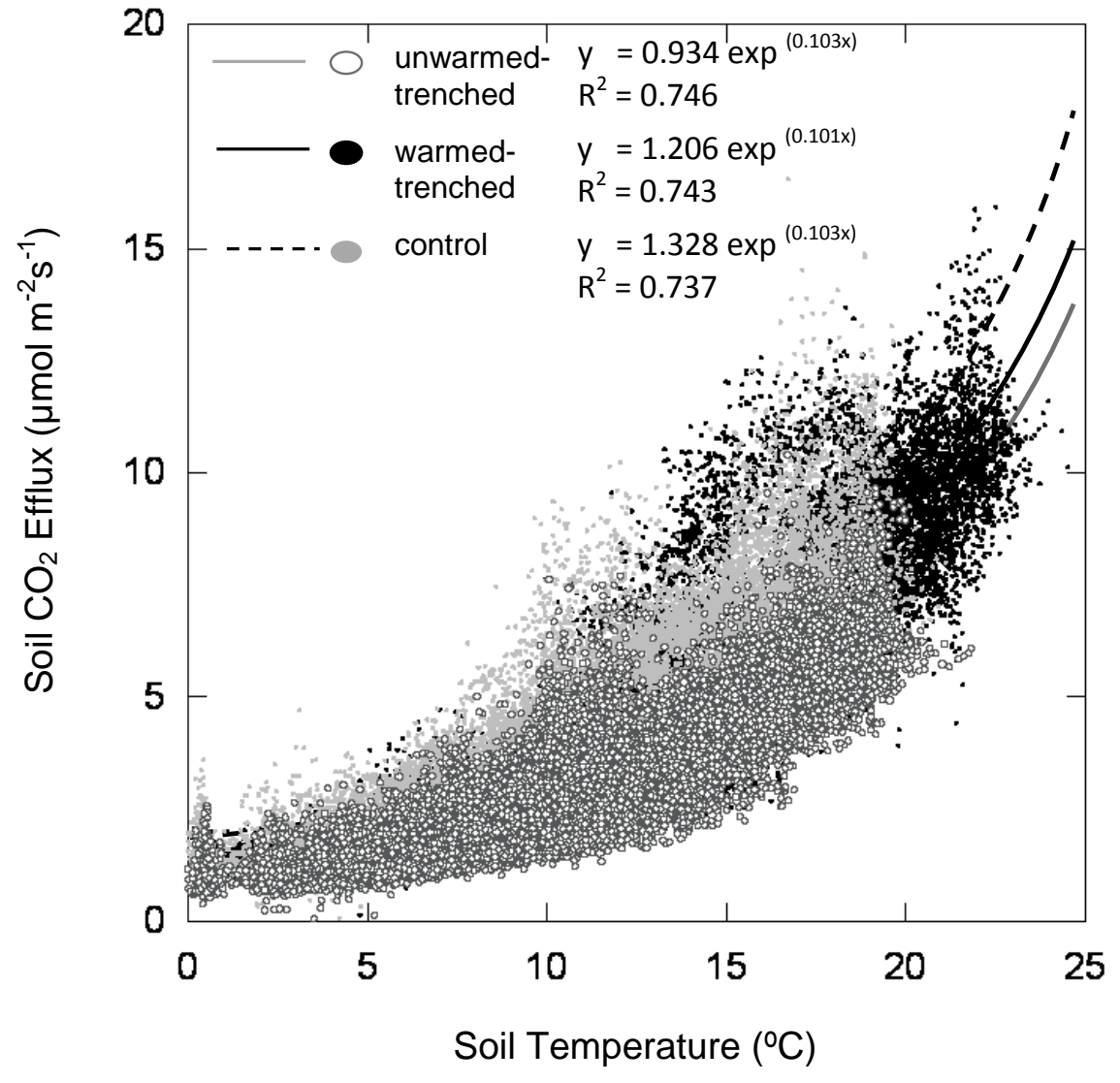

\section{BGD}

8, 6415-6445, 2011

\section{Warming effect on soil heterotrophic respiration}

M. Aguilos et al.

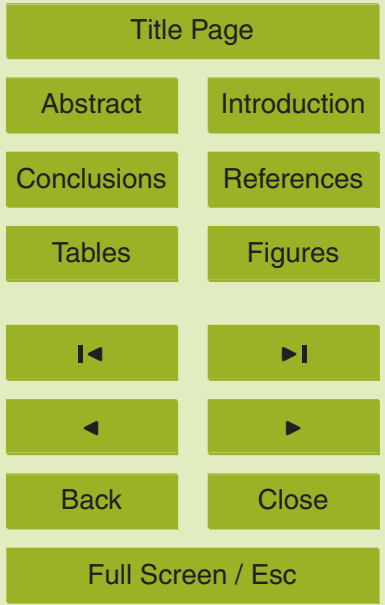

Fig. 4. Exponential correlation of soil $\mathrm{CO}_{2}$ efflux with soil temperature across the 3-yr snowfree seasons of 2007-2009. All data are hourly averages.

Printer-friendly Version

Interactive Discussion 
BGD

8, 6415-6445, 2011

\section{Warming effect on soil heterotrophic respiration}

M. Aguilos et al.

\section{Title Page}

Abstract Introduction

Conclusions

References

3

$y=1.240 \exp (0.100 x) \quad R^{2}=0.989$

$y=1.413 \exp (0.097 x) R^{2}=0.976$

0

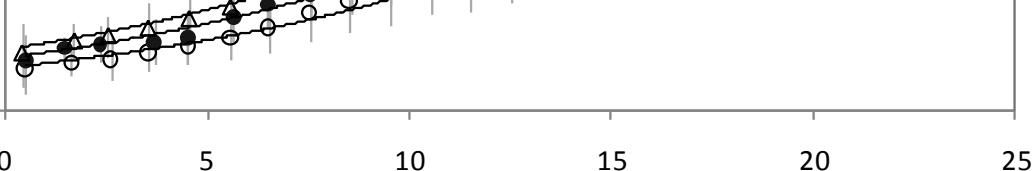

Soil Temperature $\left({ }^{\circ} \mathrm{C}\right)$

Fig. 5. Exponential relationship of soil $\mathrm{CO}_{2}$ efflux per ${ }^{\circ} \mathrm{C}$ change in soil temperature. Symbols are bin averages and error bars represent \pm 1 SD. 


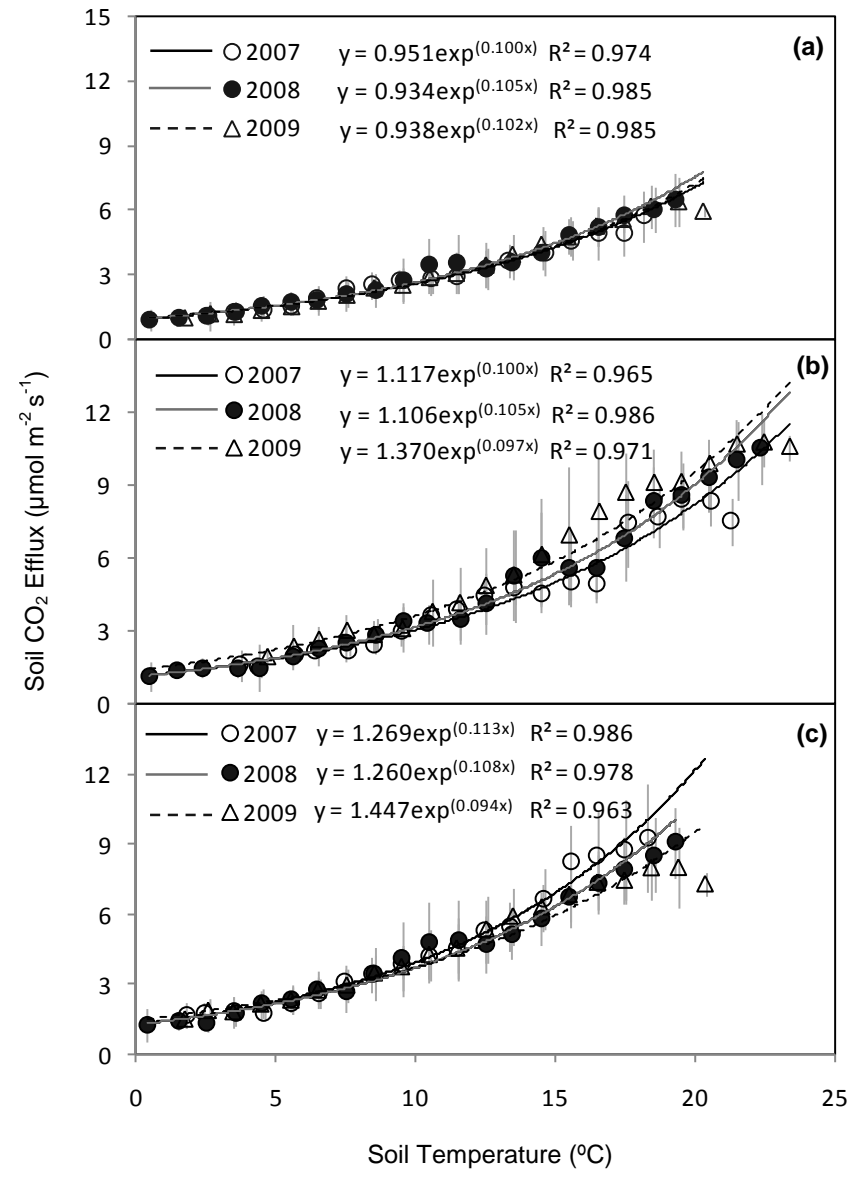

\section{BGD}

$8,6415-6445,2011$

\section{Warming effect on soil heterotrophic respiration}

M. Aguilos et al.

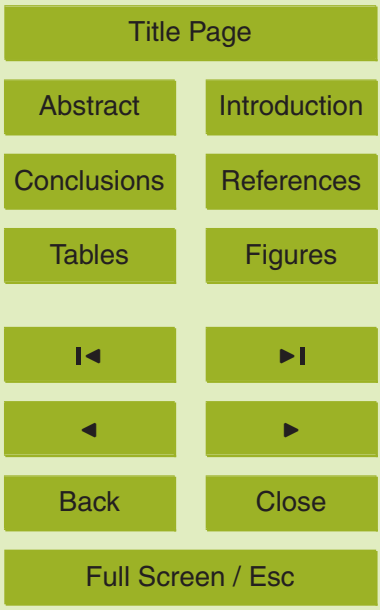

Printer-friendly Version

Fig. 6. Interannual variation in temperature dependency of soil $\mathrm{CO}_{2}$ efflux for (a) unwarmedtrenched, (b) warmed-trenched, and (c) control chambers. Symbols are bin averages and error bars represent $\pm 1 \mathrm{SD}$. 
BGD

$8,6415-6445,2011$

\section{Warming effect on soil heterotrophic respiration}

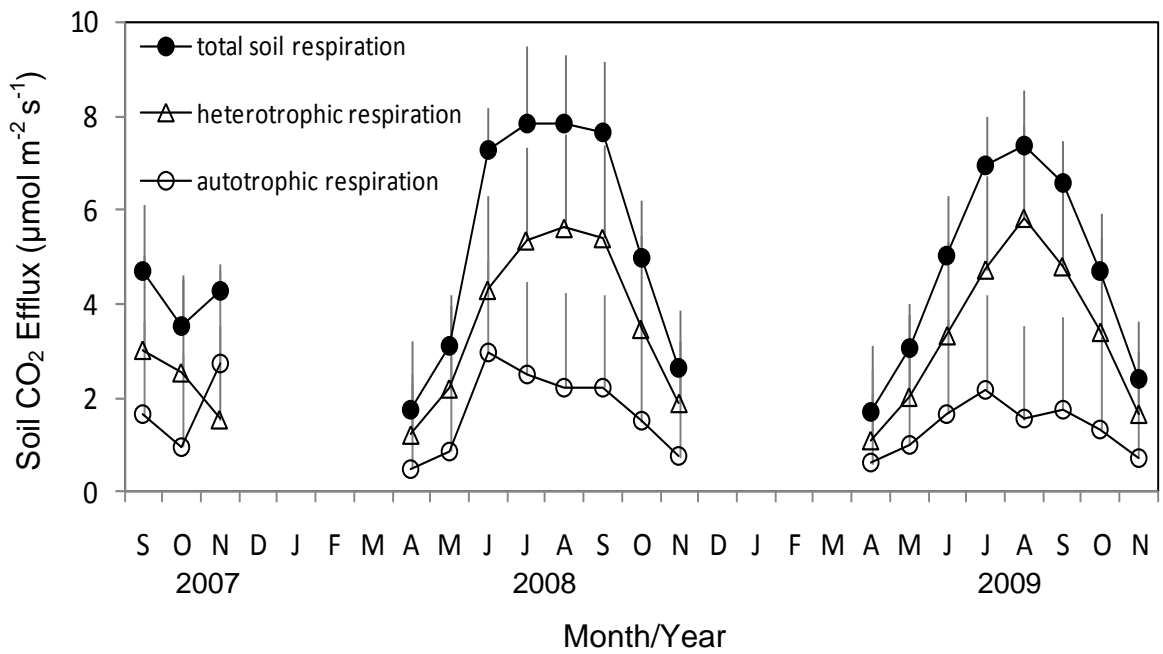

Fig. 7. Contributions of heterotrophic and autotrophic respiration to the total soil respiration over 20-month period. Symbols are monthly averages and error bars represent 1SD.
M. Aguilos et al.

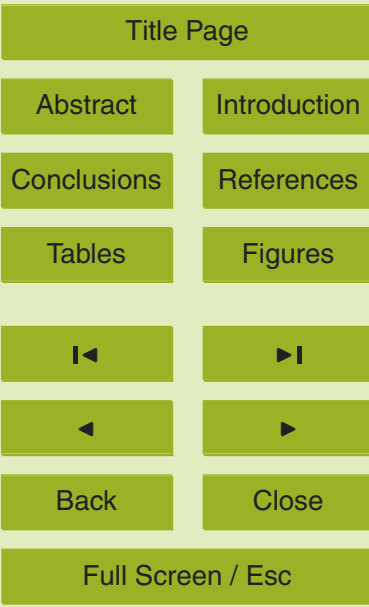

Printer-friendly Version

Interactive Discussion 
BGD

$8,6415-6445,2011$

\section{Warming effect on soil heterotrophic respiration}
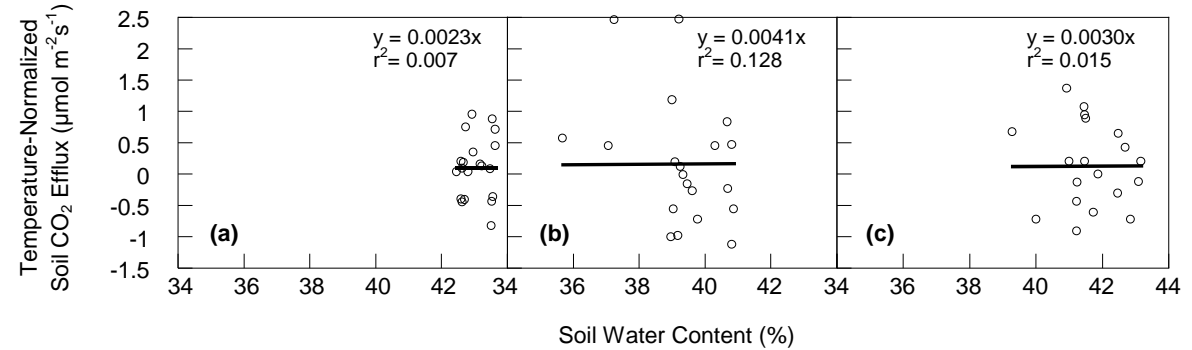

Fig. 8. Relationship of soil $\mathrm{CO}_{2}$ efflux and soil water content using the temperature-normalized efflux for (a) unwarmed-trenched, (b) warmed-trenched, and (c) control treatments. All data are monthly averages across the 20-month snow-free seasons.
M. Aguilos et al.

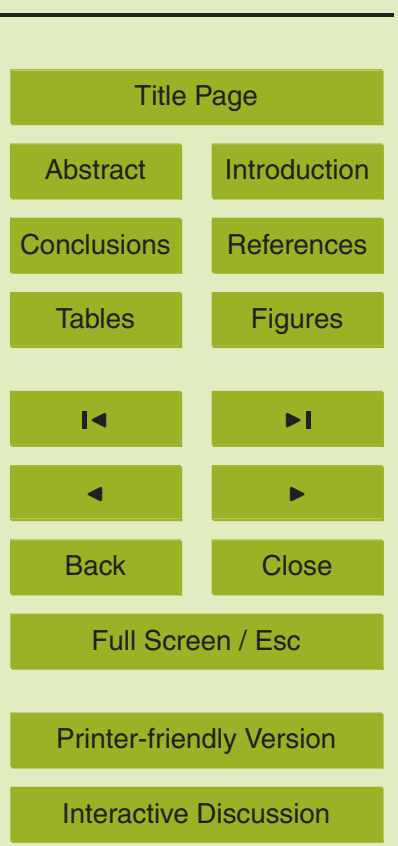

